\title{
Three-dimensional printing with biomaterials in craniofacial and dental tissue engineering
}

\author{
Wen Liao $^{1,2}$, Lin Xu ${ }^{2}$, Kaijuan Wangrao ${ }^{2}$, Yu Du ${ }^{2}$, Qiuchan Xiong ${ }^{2,3}$, Yang Yao ${ }^{\text {Corresp. } 2,3}$ \\ 1 Department of Orthodontics, West China Hospital of Stomatology,Sichuan University, Chengdu, Sichuan, China \\ 2 State Key Laboratory of Oral Diseases, West China Hospital of Stomatology, Sichuan University, Chengdu, Sichuan, China \\ 3 Department of Oral Implantology, West China Hospital of Stomatology, Sichuan University, Chengdu, Sichuan, China \\ Corresponding Author: Yang Yao \\ Email address: yaoyang9999@126.com
}

With the development of technology, tissue engineering (TE) has been widely applied in medical field. In recent years, due to its accuracy and demands of solid freeform fabrication in TE, three-dimensional printing, also known as additive manufacturing (AM), has been applied for biological scaffolds fabrication in craniofacial and dental regeneration. In this review, we have compared several types of AM techniques and summarized their advantages and limitations. The range of printable materials used in craniofacial and dental tissue includes all the biomaterials. Thus, basic and clinical studies were discussed in this review to present the application of AM techniques in craniofacial and dental tissue and their advances during these years, which might provide information for further AM studies in craniofacial and dental TE. 


\title{
1 Three-dimensional printing with biomaterials in craniofacial
}

\section{2 and dental tissue engineering}

3

\author{
Wen Liao, ${ }^{1,2}$, Lin Xu' ${ }^{1}$, Kaijuan Wangrao', Yu Du ${ }^{1}$, Qiuchan Xiong, ${ }^{1,}$, Yang Yao ${ }^{1,3}$, * \\ 1 State Key Laboratory of Oral Diseases, West China Hospital of Stomatology, Sichuan \\ University, Chengdu, Sichuan, China \\ 2 Department of Orthodontics, West China Hospital of Stomatology, Sichuan University, \\ Chengdu, Sichuan, China
}

3 Department of Oral Implantology, West China Hospital of Stomatology, Sichuan University, Chengdu, Sichuan, China

\section{* Corresponding author} Yang Yao D.D.S., Ph.D.

State Key Laboratory of Oral Diseases \& Department of Oral Implantology, West China Hospital of Stomatology, Sichuan University, Chengdu, Sichuan, China E-mail: yaoyang9999@126.com

\begin{abstract}
With the development of technology, tissue engineering (TE) has been widely applied in medical field. In recent years, due to its accuracy and demands of solid freeform fabrication in TE, threedimensional printing, also known as additive manufacturing (AM), has been applied for biological scaffolds fabrication in craniofacial and dental regeneration. In this review, we have compared several types of AM techniques and summarized their advantages and limitations. The range of printable materials used in craniofacial and dental tissue includes all the biomaterials. Thus, basic and clinical studies were discussed in this review to present the application of AM techniques in craniofacial and dental tissue and their advances during these years, which might provide information for further AM studies in craniofacial and dental TE.
\end{abstract}


30

31

32

33

34

35

36

37

38

39

40

41

42

43

44

45

46

47

48

49

50

51

52

53

54

55

56

57

58

59

60

61

62

63

64

65

66

67

68

69

\section{Introduction}

The development of tissue engineering (TE) and regeneration constitutes a new platform for translational medical research. It has already been an important kind of therapeutic method in craniofacial and dental field, such as trauma, skeletal disease, wound surgery and periodontal disease (Rai et al., 2017). There are several approaches to develop scaffolds, such as electrospinning, mold casting, salt leaching, sintering and freeze drying. Some of these methods are easy and inexpensive, such as mold casting and salt leaching. Some can fabricate three dimensional scaffolds with good structure with a comparatively high speed, such as electrospinning, however, none of them can solve the problem of solid freeform fabrication. Solid freeform fabrication of three-dimensional scaffolds with complex space structure, not only the irregularly curved external structure, but also the internal porous structure, is important in craniofacial and dental regeneration because of its anatomical limitations. Therefore, attempts to improve design and fabrication of bio-active scaffolds, especially on freeform fabrication comprise majority of studies in biomaterial researches. Recently, additive manufacturing (AM) has been applied for scaffold developing (He et al., 2015). This method was firstly introduced by Herver Voelcker in 1970 to describe the algorithms for the purposes of 3D solid modeling. AM has been widely used in industry because of its accuracy of shaping (Torres et al., 2011). It helps researchers to meet the demands of solid freeform fabrication in TE, too (Warren et al., 2003; Obregon et al., 2015). It has unique advantages in fabrication of patient-specific scaffold with multiple materials, too. In some recent advances, materials with live cells were used, made it possible for constructing organ and tissue using AM (Mannoor et al., 2013).

Another hot spot of study in the field of tissue engineering combined with material manufacturing methods is electrospinning. Electrospinning uses electrostatic principle to manufacture the nanofibers required for TE applications (Zamani et al., 2018). There are mainly three types of technique: blending electrospinning, coaxial electrospinning, and emulsion electrospinning, they share the same basis (Lu et al., 2016; Tong et al., 2012). There is a high electric field applied to draw a polymer solution between the injection needle and a collector. The polymer forms a suspended drip and is stretched into a conical shape called "Taylor Cone" by the high voltage power. Then the charged droplet forms a charged jet by breaking free from the surface tension of the top droplet. Due to the evaporation of the solvent or the curing cooling of the solute and melt, the charged jet finally condenses into filaments and deposits on the collecting plate in the form of nonwovens (Barnes et al., 2007; Nair et al., 2004; Chan et al., 2009). The nanofibers prepared by electrospinning have large specific surface area and high porosity in three-dimensional structure, which makes electrospinning nanofiber membranes have a wide application value in many fields (Qian et al., 2011; Chung et al., 2010). It's worth mentioning that bio-electrospraying and cell electrospinning, both based on this principle, were firstly used to deal with living cells and whole organisms in 2005/06 (Jayasinghe et al., 2006; TownsendNicholson \& Jayasinghe, 2006). A series of studies have confirmed that this high-strength electric field drive technology, naming bio-electrospraying, showed no significant side effect on the bioactivity of living samples (Jayasinghe, 2011). Cell electrospinning is a leading technology 
70 in the formation of cell fibers and stents that can be used to create a variety of biological

71 structures, from simple cell stents and diaphragms to more complex structures (Jayasinghe,

72 2013). In the recent years, bio-electrospraying and cell electrospinning have attracted significant

73 increasing amount of interest.

74 Here we review the application of AM techniques in craniofacial and dental TE. First, we will

75 describe the types and strategies of four typical AM printers used by tissue engineering

76 researchers most frequently, along with their advantages and limitations. Then, we will present

77 recent advances of AM related with craniofacial bone, craniofacial cartilages and dental tissue.

78 Finally, we will look ahead to recommend the future possible AM research field in craniofacial

79 and dental TE.

80

\section{Survey methodology}

82 PubMed and Web of Science databases were searched (until January 2018) using the following

83

84

85

86

87

88

89

90

91

92

93

94

95

96

97

98

99

100

101

102

103

104

105

106

107

108

109

free-text terms: additive manufacturing, craniofacial/dental tissue engineering.

\section{AM Approaches in craniofacial and dental TE}

\subsection{Selective Laser Sintering (SLS)}

SLS was developed by Carl Deckard at the University of Texas and described in his master's thesis (Deckard, 1991; Deckard et al., 1992; Beaman \& Deckard, 1990). Its fundamental principle is to control the laser concentrated infrared heating beam to melt free powders together to generate a precise structure. In a SLS printer, a fabrication chamber is settled at the base, filling with tightly compacted plastic powder. The temperature of the chamber is kept just below the melting point of free powder. While the laser beam moves under the guidance of scanner system and computer code, precisely shaped monolayer is printed by causing the temperature to rise above the melting point of plastic powder (Melchels et al., 2010) (Figure1 A Schematic of SLS). As a result, morphology and melting temperature of the powder are considered as the two crucial parameters in laser sintering (Mazzoli, 2013). According to the mechanism of SLS, the heating temperature should be able to melt the surface layer. The molten materials on the surface then work as binder to connect neighboring non-molten particle cores (Mazzoli, 2013). This socalled "partial melting" phenomenon was modeled first by Fischer (Fischer et al., 2002). The laser sintering powder is commercially available. They are polymeric materials such as poly(L-lactide) (PLLA) /carbonated hydroxyapatite (CHA) (Zhou et al., 2008), polyvinyl alcohol (PVA) (Chua et al., 2004) and poly-e-/caprolactone (PCL) (Williams et al., 2005). In a SLS printer, polymeric powder have a $50 \mu \mathrm{m}$ mean particle size diameter (Mazzoli, 2013).

Many advantage of SLS method, such as accuracy, fast fabricating, low price, elective powder type, no need of supporting material, can be documented (Mazzoli et al., 2007). The disadvantage of SLS is that with crucial laser power and scanning speed, there is limit in the size of object fabricated with the commercially obtained machines. What's more, this method cannot fabricate scaffolds with hydrogel material (Duan \& Wang, 2011).

\subsection{Stereolithography (SLA)}


110 SLA printing was firstly published in 1986, in U.S. patent Apparatus for production of three111 dimensional objects by stereolithography (Hull, 1986). He first exploited the spatially controlled 112 solid transition of liquid-based resins by photopolymerization to produce complex structures 113 layer-by-layer in SLA approach (Skoog et al., 2014). In brief, a computer-controlled laser beam 114 moves and cures the top liquid resin by photopolymerization. The polymerized resin adhere to a 115 building platform for support. After finishing the first layer, the building platform drops a 116 defined distance under the liquid surface and the above steps repeats to cure a second layer 117 (Figure1B Schematic of SLA).

118 This technique was later modified by application of digital light projector, known as digital light 119 processing (DLP). It enables architectures built from the bottom of the building platform. After 120 finished the first layer, the platform raises a short distance from the liquid surface and curing 121 procedure repeats. It looks like the structure is lift by the platform, so that the resin required is 122 significantly reduced. Since DLP derived initially from SLA and they share close concepts, in 123 this review, we use SLA to refer to them both. Taking advantage of the extreme accuracy of laser

124

125

126

127

128

129

130

131

132

133

134

135

136

137

138

139

140

141

142

143

144

145

146

147

148

149 light, SLA printer has been largely used to build complex and precise structures. Most commercial systems have the capacity to fabricate structures with a resolution of $50 \mu \mathrm{m}$. On the other hand, the major limitation of SLA also lies on stereolithography, which limits choices of resins. Most of SLA resins are based on low molecular weight, multi-functional monomers for they formed highly cross-linked networks. Poly (propylene fumarate) (PPF) is the most often used polymer in the fabrication of tissue scaffolds with SLA because of its favorable biocompatibility and photo-cross linking functionality. Although only a limited selection of photocurable resins have been used in SLA, such as PPF and polyurethane (PU) (Hung et al., 2014a), efforts have been made to improve the features of photocurable materials for TE usage, in order to create biodegradable materials (Skoog et al., 2014) and cell-compatible photocurable hydrogels, in the past decade.

\subsection{Fused deposition modeling (FDM)}

FDM is another common AM technique, which was first used in the 1990s (Cai et al., 2005). The printing process of FDM is based on layer-by-layer deposition of thermoplastic polymers. Due to a solid-semiliquid state transition, thermoplastic polymeric filament is extruded as the "ink" from a high temperature nozzle (usually $95^{\circ} \mathrm{C}-230^{\circ} \mathrm{C}$ ). After printing the pattern of the first layer on a surface, either the nozzle rises, or the platform descends in the Z-axis direction at a thickness of a monolayer under the control of computer. The process is repeated until structure generation is completed (Korpela et al., 2013). Depending upon the polymer material and the design, the FDM printer usually prints 3D structures with a typical thickness of 100-300 $\mu \mathrm{m}$ (Cai et al., 2005) ( Figure 1C Schematic of FDM).

This technique has unique advantages because of its wide-ranged operating temperature, user friendly control system, and large number of commercial platforms. Several kinds of biodegradable materials have been used in the process, including polylactic acid (PLA), PVA, PCL, poly (D, L-lactide-co-glycolide) (PDGA) and poly (D, L-lactide) (PDLLA). Several polymers, such as PLA, PCL and PVA, are extensively utilized for their considerable 
150 biocompatibility and biodegradation. With some modification of the printer, hydrogels such as

151

152

153

154

155

156

157

158

159

160

161

162

163

164

165

166

167

168

169

170

171

172

173

174

175

176

177

178

179

180

181

182

183

184

185

186

187

188

189

alginate, collagen, decellularized ECM, and marine products such as biogenic polyphosphate (Bio-PolyP) and biogenic silica (Bio-Silica) (Wang et al., 2013; Wang et al., 2014) can be used as well, providing possibility of loading live cells in printing progress.

However, FDM has a significant drawback, which is the lowest precision among the four methods. The minimal scale of the printing bar is about $0.1 \mathrm{~mm}$ (Cai et al., 2005). It is also difficult to generate micro-porous structures for bone TE without further modifications. In addition, as it is printing in an open space, external supports is needed to get rid of the collapse of structures. After finishing the printing, those supports must be removed carefully.

\subsection{Binder Jetting}

Binder jetting is a technology developed at almost the same period with FDM. Its first development is in the early 1990s (Sachs et al., 1990). In 2010, the first binder jetting machine was commercially obtained. Its basic working process shares many similarities with inkjet printing (Meteyer et al., 2014). In a binder jetting printer, liquid binder is printed as "ink" onto powder container. Then a new consecutive solid thin layer of free powder will be put on the binder. This printing process repeats until work finishes. The structures printed by binder jetting printers have layer thickness among 76-254 $\mu \mathrm{m}$ (Torres et al., 2011) (Figure 1D Schematic of binder jetting). The advantage of this method is that binder jetting printer has various choices of printable materials: high-performance composites are used to produce tough, strong, colored, and best resolution models, elastomeric materials which give rubber-like properties or casting material which enables the creation of metal prototypes (He et al., 2015). Anoth 'er advantage is parts can be produced with no need of supporting structure, so it is more applicable in complicated 3D structure establishment (Gokuldoss et al., 2017). This method has a faster printing speed than other AM methods, which can be accelerated by using multiple print heads. On the other hand, the disadvantage of this method is also clear. A lot of post-printing treatment increased the time and financial cost. The control of pore existence, size and shape is difficult because material is stacked, not melted together.

\section{Current status and challenges of $\mathrm{AM}$ applications for craniofacial bone, cartilage and dental tissues.}

\subsection{AM application in craniofacial bone TE}

\subsubsection{Polymer biomaterials for craniofacial bone TE}

Fabricating maxillofacial bone scaffold is a major application of AM technology in craniofacial usage. The selection of an ideal bone graft material relies on multiple factors such as material viability, graft size, porosity, hydrophilic, biodegradability, osteoconductivity and osteoinductivity. It was first reported that synthetic polymeric materials could generate AM bone scaffolds. Many polymers are printable, for they often have proper melting ranges to fulfill the technique requirement of shaping with FDM or binder jetting. As far back as in 1996, PLA was used as AM material in computer aided design (CAD) bone generation (Giordano et al., 1996). After that, other polymeric scaffolds have been increasingly developed in AM techniques, such 
190

191

192

193

194

195

196

197

198

199

200

201

202

203

204

205

206

207

208

209

210

211

212

213

214

215

216

217

218

219

220

221

222

223

224

225

226

227

228

229

as PCL (Williams et al., 2005; Lohfeld et al., 2012; Korpela et al., 2013; Van Bael et al., 2013; Temple et al., 2014a), poly(lactic-co-glycolic acid) (PLGA) (Luangphakdy et al., 2013), poly(trimethylene carbonate) (PTMC) (Blanquer et al., 2012) and so on. As a widely used biomedical material, PLA has good biocompatibility as implants with FDA clearance. Printed PLA bars have physical properties of maximum measured tensile strength. Low molecular weight PLLA (53 000)'s maximum measured tensile strength is $17.40+/-0.71 \mathrm{MPa}$, while that of high molecular weight PLLA (312 000) is $15.94+/-1.50 \mathrm{MPa}$ (Giordano et al., 1996). PCL is an alternative with PLA because it does not release acid in PLA remodeling. This means it is more resistant in vivo. PCL also has a lower glass transition temperature and melting temperature, making it superior to PLA in certain bone grafting applications. For instance, PCL can be easily blended with other materials, including tricalcium phosphate (TCP), hydroxyapatite (HA) and bioactive glass (BAG), due to its low melting temperature (Korpela et al., 2013). In addition, the compressive module of PCL can be increased up to $30-40 \%$ by adding $10 \mathrm{wt} \%$ of BAG.

As modifications for the mechanical performances (Duan \& Wang, 2010), polymers are also blended in defined ratios to make printable composites, such as PCL/PLGA by FDM (Shim et al., 2014) and PLGA/PVA by binder jetting (Ge et al., 2009). PVA also serves as a porogen in the printed architectures by taking advantage of its water-soluble properties. PVA-blended HA was printed by SLS to study the feasibility of composite scaffold (Simpson et al., 2008). SEM observations showed significant improvements in the sintering effects and to be a suitable material when processed by SLS for TE scaffolds.

\subsubsection{Cells and animal models used in craniofacial bone $T E$}

The selection of cell is important for bone TE. For orthopedic and maxillofacial researches, primary stem cells as bone marrow stromal cells (BMSC) (Fedorovich et al., 2009; Rath et al., 2012) and adipose derived stem cells (ADSC) (Temple et al., 2014a) are wildly applied to seed cell types. Fibroblasts are used for viability test and proliferation essay, as well as human multipotent dental neural crest-derived progenitor cells (dNC-PCs) (Fierz et al., 2008). Multiple bone cell lines are applied in AM studies, including MC3T3-E1 (Leukers et al., 2005; Khalyfa et al., 2007; Lan et al., 2009; Melchels et al., 2010; Blanquer et al., 2012), SaOS-2 (Duan \& Wang, 2010; Wang et al., 2013), C3H/10T1/2 cells (Inzana et al., 2014) and MG-63 (Feng et al., 2014a; Feng et al., 2014b). With osteogenic induction, the attached bone cells not only exhibited cell viability around $60 \%-90 \%$, but also kept potential of osteogenic differentiation which is confirmed by observing bone metabolism related RNA and protein expression, such as runtrelated transcription factor 2 (RUNX2), bone morphogenetic proteins (BMPs), alkaline phosphatase (ALP) and osteonectin (ON) activity. For cells used in craniofacial bone TE, there are different advantages for different cells. Bone cell lines as MC3T3-E1, SaOS-2, c3h/10T1/2, MG-63 were often used for initial screening of biological activity of materials (Przekora, 2019). Since these cells are tumor-derived cell lines or immortalized osteoblast cell lines, their gene expressions are quite different from those of primary cells (Pautke et al., 2004). The best seed cells for craniofacial bone TE are still considered to be primary OBs because of their behavior in 
230

231

232

233

234

235

236

237

238

239

240

241

242

243

244

245

246

247

248

249

250

251

252

253

254

255

256

257

258

259

260

261

262

263

264

265

266

267

268

studying osteoconductive and osteopromotive properties (Przekora, 2019). The advantages of using stem cells also include testing the osteoconductive ability of printing materials (Temple et al., 2014b). What's more, many kinds of tissue can be the source of autologous stem cells. Several animals had been taken in AM mandible scaffold research. Rabbits are most frequently used in the study of mandibular bone repair (Alfotawei et al., 2014). A protocol described the usage of three-dimensional printed scaffolds with multipotent mesenchymal stromal cell (MSCs) in mandibular reconstruction of rabbits. They used BMSC and ADSC from rabbits (Fang et al., 2017). One of the previous studies was performed on six mature minipigs (Figure 2). The researchers created four mandibular defects on each pig. After the defect sites were modelled by $\mathrm{CAD} / \mathrm{CAM}$ techniques, scaffolds with complex geometries and very fine structures were produced by AM technology. Then the autologous porcine bone cells were seeded on these polylactic acid/polyglycolic acid (PLA/PGA) copolymer scaffolds. Implanting these tissueconstructs into the bone defects supported bone reconstruction (Meyer et al., 2012). What's more, in a recent study, researchers proved that the craniofacial reconstruction including mandible could be achieved through 3D bioprinting. They presented an integrated tissue-organ printer (ITOP) that can fabricate stable, human-scale tissue constructs of any shape. They also found vascularized bone growth in the central and peripheral portion in vivo trails of rats (Kang et al., 2016). For periodontal bone regeneration, at least $4 \mathrm{~mm}$ augmentations of craniofacial bone had already been achieved with synthetic monetite blocks. 3D printing TCP plates were used as onlay grafts in periodontal surgery. The 4.0- and 3.0-mm high blocks were filled with newly formed bone with $35 \%$ and $41 \%$ of respective volumes (Torres et al., 2011). These 3Dprinted customized synthetic onlay grafts were further used in dental implant surgery to achieve bone augments (Tamimi et al., 2014). Direct writing (DW) technology had been applied to produce a TCP scaffolds to repair the rabbit trephine defect. The scaffolds had micropores ranging from $250 \times 250 \mu \mathrm{m}$ up to $400 \times 400 \mu \mathrm{m}$. After 16 weeks, $30 \%$ of the scaffold was remodeled by osteoclast activity with new bone filling in the scaffolds and across the defects (Ricci et al., 2012). These studies suggested that AM scaffold with tissue engineering could be used in human craniofacial defect repair in the future.

\subsubsection{Technique challenges for craniofacial bone printing and current strategies}

Although cell migration and proliferation inside the porous scaffold were observed in an AM HA scaffolds with inner-connective pores (Fierz et al., 2008), for all the porous scaffolds, it is still a big challenge to keep good cell viability in the central area. Insufficient nutrition and oxygen in static culture lead to cell necrosis and make low cell density area. Method of dynamic cultivation can partly solve this problem. A dynamic cultivation system by perfusion containers strongly increased the MC3T3-E1 population compared to the static cultivation method in a 7-day in vitro cultivation. Close contact between cells and HA granules were observed deeply in the printed structure (Leukers et al., 2005). In another study, application of perfusion bioreactor system to a BCP binder jetting fabricated scaffold not only successfully reversed the decreased $\mathrm{OB}$ and BMSC cell numbers but also increased their differentiation potential (Rath et al., 2012). 
269 Incomplete healing is another current limitation to AM bone grafts. Therefore, growth factors are 270 applied in scaffolds. Bone morphology protein-2 (BMP2), a bone growth factor with strong bone 271 induction property, is often used. The controlled release of BMP2 can be achieved by surface 272 coating or nanoparticles embedding. More consideration is required according to the printing 273 procedure for AM scaffolds. BMP2 loaded gelatin microparticles (GMPs) was used as a 274 sustained release system and dispersed in hydrogel-based constructs, comparing with direct 275 inclusion of BMP2 in alginate or control GMPs (Poldervaart et al., 2013). In another study with a 276 multi-head deposition system (MHDS), rhBMP2 was loaded by either gelatin (for short-term

277

278

279

280

281

282

283

284

285

286

287

288

289

290

291

292

293

294

295

296

297

298

299

300

301

302

303

304

305

306

307

308 delivery within a week) or collagen (for long-term delivery up to 28 days) and dispensed directly into the hollow microchannel structure of PCL/PLGA scaffold during the printing process (Shim et al., 2014). The in vivo micro-computed tomography (micro CT) and histological analyses indicated that CL/PLGA/collagen/rhBMP2 scaffolds lead to superior bone healing quality at both 4 and 8 weeks, without inflammatory response. Transforming growth factor- $\beta$ (TGF- $\beta$ ) was another important growth factor widely used in osteoblast differentiation and animal models (Nikolidakis et al., 2009).

Due to the hydrophobic feature of most printable materials, surface modification can be exploited to improve biocompatibility. Collagen is a widely used coating material for AM bone scaffold coating. The flexural strength and toughness of a calcium phosphate scaffold was significantly improved by coating a $0.5 \mathrm{wt} \%$ collagen film (Inzana et al., 2014). Biomimetic and $\beta$-TCP (Luangphakdy et al., 2013) can enhance the surface roughness and increase bone differentiation, thus may minimizing the need for expensive bone growth factors (Gibbs et al., 2014) (Table 1).

\subsection{AM application in craniofacial cartilage}

\subsubsection{Polymer biomaterials for craniofacial cartilage $T E$}

Cartilage is one of the few tissues that are not vascularized, which makes its regeneration unique. The most widely applied techniques in cartilage printing included FDM, SLA and SLS. For cartilage repair, polymeric materials like PLA, PCL as well as PLGA were most common cartilage scaffolds. Another kind of major material was the hydrogel. Hydrogel could mimic the elastic module of cartilage and have been applied for cartilage reparation for a long time. Recent study showed PEG hydrogel had promising potential for cartilage bioprinting (Cui et al., 2012).

\subsubsection{Cells for craniofacial cartilage TE in AM approaches}

Chondrocytes were the standard seed cells in cartilages TE, but chondrocytes from different cartilage subtypes exhibited different differentiation. In AM cartilage regeneration, to generate different cartilage subtypes, chondrocytes were harvested from several kinds of cartilages. In one research, rib cartilage cells were co-cultured with adherent stromal cells in a porous PCL scaffolds fabricated by FDM, making a culture system which may have potential of clinical usage (Cao et al., 2003). In one research, porcine articular chondrocytes were seeded in PLGA scaffold fabricated with liquid-frozen deposition manufacturing, cultured for a total of 28 days. Final results showed that cells proliferated well and secreted abundant extracellular matrix (Yen et al., 2009). Not only chondrocytes, but also stem cells were also applied in cartilages TE, such 
309

310

311

312

313

314

315

316

317

318

319

320

321

322

323

324

325

326

327

328

329

330

331

332

333

334

335

336

337

338

339

340

341

342

343

344

345

346

347

348

as MSCs and so on (Pati et al., 2015). Interestingly, bone marrow clots (MC) as a promising resource proved to be a highly efficient, reliable, and simple cell resource that improved the biological performance of scaffolds as well. The FDM printed PCL-HA scaffold incubated with MC exhibited significant improvements in cell proliferation and chondrogenic differentiation. This study suggested that $3 \mathrm{D}$ printing scaffolds, $\mathrm{MC}$ could provide a promising candidate for cartilage regeneration (Yao et al., 2015). Stem cell-based approach and chondrocyte-based approach were common choices for cartilage regenerations. The major advantage of using stem cells is that autologous transplantation can be implemented (Walter et al., 2019). Unlike chondrocytes, autologous stem cells, such as BMSCs or ADSCs, are rich in source. Xenografts of chondrocytes is not a good choice for human cartilage repair for there are immunological reactions (Stone et al., 1997). It is also reported that chondrocytes lost the chondrogenic differentiation after several passages (von der Mark et al., 1977; Frohlich et al., 2007). On the other hand, the stem cells may form fibrocartilage-like tissue in defect without grows factors (Yoshioka et al., 2013). Differences in depth of the defect also affect the cartilage regeneration, which should be selected according to research purposes (Nixon et al., 2011).

\subsubsection{AM application for TMJ cartilage}

Temporal mandibular joint (TMJ) disc is a heterogeneous fibrocartilaginous tissue which plays a vital role in its function. It was reported recently that researchers had developed TMJ disc scaffold with spatiotemporal delivery of connective tissue growth factor (CTGF) and transforming growth factor beta 3 (TGF 33 ) which induced fibrochondrogenic differentiation of MSCs. They used layer-by-layer deposition printing technique with polycaprolactone (PCL) to fabricate the scaffold. CTGF and TGF $\beta 3$ were used as growth factors and human MSCs were used as seeding cells. After 6 weeks of cell culture, it resulted in a heterogeneous fibrocartilaginous matrix which was similar with the native TMJ disc in structure. Due to the possible effect of remaining PCL scaffold structure, the mechanical properties of the engineered TMJ discs by 6 weeks were approximated to the native properties (Legemate et al., 2016). Schek et al. used image-based design (IBD) and solid free-form (SFF) fabrication techniques to generate biphasic scaffolds. They found the growth of cartilaginous tissue and bone tissue after seeding different cells which demonstrated the possible therapy to regenerate TMJ joints (Figure 3) (Schek et al., 2005). In another study, researchers found that poly (glycerol sebacate) (PGS) might be potential scaffold material for TMJ disc engineering (Hagandora et al., 2013).

Considering the complex geometries of TMJ cartilage, AM techniques have great potential in its fabrication, and further exploration is needed in customized TMJ cartilage engineering.

\subsubsection{AM application for other craniofacial cartilages: ear, nose and throat}

Other than TMJ, in craniofacial area, cartilage also forms ear, nose, and larynx. Anatomically shaped ear, nose and throat were already printed through PR approaches. PCL-based ear and nose scaffold were printed and perfused with type I collagen containing chondrocytes. The samples were implanted into adult Yorkshire pigs for 8 weeks and histologically analyzed. Histological evidences present that they resulted in the growth and maintenance of cartilage-like tissue (Zopf et al., 2015). A bionic ear was printed with precise anatomic geometry of a human 
349

350

351

352

353

354

355

356

357

358

359

360

361

362

363

364

365

366

367

368

369

370

371

372

373

374

375

376

377

378

379

380

381

382

383

384

385

386

387

388

ear by alginate as matrix with 60 million chondrocytes per milliliter. An electrically conductive silver nanoparticle (AgNP) was also printed and infused inductive coil antenna as the sensory part of the ear, connecting to cochlea-shaped electrodes supported on silicone. After in vitro culture, this printed bionic ear not only demonstrated good biocompatibility, but also exhibited enhanced auditory sensing for radio frequency reception, which mimicked the functional human ears (Mannoor et al., 2013). Functional Tissue-engineering tracheal reconstruction has also been reported on rabbits by 3D printed PCL scaffolds. The shape and function of reconstructed trachea were restored successfully without any graft rejection. Histological results showed proper cartilage regeneration (Chang et al., 2014).

\subsubsection{Technique challenges for cartilage printing and current strategies}

A highlight in cartilage printing is that cells can be printed together with gels as cell vectors. For printing of cell-laden material, the important criterions lay on the suitable shear force and temperature. Otherwise, damage may occur to cells and reduce the viability in the printed constructs (Derby, 2012; Pati et al., 2015). Some studies have been paying attention to modification of the printer nozzle and materials. In one study, an electrospun head was added on an inkjet printer and print electrospun PCL film with fibrin-collagen hydrogel-based cartilage layers inside. It is designed for printing a fibrin-collagen hydrogel of five layers in only $1 \mathrm{~mm}$ thickness. With this multi-layer scaffold, this research successfully enhanced the strength of printed materials and overcame the major limitation of inkjet printer in material's loading ability. So it is possible to be used to print some load bearing tissue such as cartilage (Xu et al., 2013) (Table 2).

\subsection{AM applications in dental tissue}

TE strategies for tooth and periodontal tissue regeneration have been increasingly explored recently even though the implanting of titanium artificial tooth root is clinically more and more mature (Ohazama et al., 2004; Monteiro \& Yelick, 2017). By now, two tissue regeneration surgical procedures, guided bone regeneration (GBR) and guided tissue regeneration (GTR) have already been applied in dental clinic and proved to have reliable effect on bone and gingival regeneration (Bottino et al., 2012). Few clinical methods can be applied in dental tissue regeneration; however, a lot of AM researches were done in this field. Multiple kinds of cells involve in the progress of dental tissue formation, including ameloblasts for enamel, odontoblasts for dentin, cementoblasts for cementum, and cells of multiple lineages including mesenchymal, fibroblastic, vascular, and neural cells that form dental pulp (Fisher et al., 2002; Xue et al., 2013; Park et al., 2014a; Jensen et al., 2014a). Dental tissue includes composites of enamel, dentin and pulp, periodontal ligament, cementum, and so on. Since the dental tissue are related with each other, some researches chose to establish combined dental tissue like scaffolds with AM technology, such as cementum/dentin interface (Lee et al., 2014a) or cementum/PDL interface (Cho et al., 2016a). Various materials can be used in AM technology for dental tissue (Table 3).

As a result, we divide the load of press into one (single) tissue regeneration and multi (combined) tissue regeneration and reviewed them one by one.

\subsubsection{Single dental tissue regeneration}


389 Mao's group had done tooth and periodontal regeneration by cell homing. The research starts 390 from bioprinting of PCL-HA material into two kinds of anatomically tooth shaped scaffold by

391

392

393

394

395

396

397

398

399

400

401

402

403

404

405

406

407

408

409

410

411

412

413

414

415

416

417

418

419

420

421

422

423

424

425

426

427

428

SLA technology, one is human molar scaffold, and another is rat incisor scaffold. Growth factors of bone morphogenetic protein-7 (BMP7) and stromal cell-derived factor-1 (SDF1) were added into the scaffold to active cell homing in vivo. These two scaffolds were orthotopically and ectopically implanted into mandibular incisor extraction socket and dorsum subcutaneous pouches of rats. After 9 weeks, tooth-like structures and periodontal integration were successfully generated by their study with endogenous cell homing and angiogenesis (Kim et al., 2010). High survival rates were reported in a self-defined shape engineered pulp, which was as high as $87 \% \pm 2 \%$. This research was done to establish a dental pulp like tissue with human dental pulp cells (hDPCs) in sodium alginate/gelatin hydrosol (8:2), and an amount of $1 \times 10^{6}$ cells $/ \mathrm{ml}$ were seeded (Xue et al., 2013). In a recent research, to generate artificial periodontal ligament (PDL) tissue, human PDL cells were seeded on anatomically FDM printing PCL/HA scaffolds. In periodontal osseous fenestration defects on nude mice, guided fiber alignment was later observed oblique orientation to the root surface 6 weeks post implant, which mimics the mature PDL fiber aliment (Park et al., 2014b). Another study invested the osteogenic potential of human dental pulp stem cells (hDPSCs) on different porous PCL printing scaffolds. This research used a specially designed double-layer scaffold system for better osteogenic differentiation. The first layer was nanostructured porous PCL (NSP-PCL) scaffold, and the second layer was PCL coating with a mixture of hyaluronic acid and beta-TCP (HT-PCL) scaffold. With 21 days of in vitro cultivation, the NSP-PCL and HT-PCL scaffolds promoted osteogenic differentiation and $\mathrm{Ca}^{2+}$ deposition, showing promising application periodontal tissue regeneration (Jensen et al., 2014b). A very recent clinic case first showed the SLS printed PCL scaffolds' application on a periodontal tissue regeneration in a periodontitis patient. The case demonstrated a $3 \mathrm{~mm}$ gain of clinical attachment and partial root coverage. However, the scaffold became exposed at the $13^{\text {th }}$ month and been removed. Even though, it showed huge potential of AM applications for dental tissues (Rasperini et al., 2015) (Figure 4).

\subsubsection{Combined dental tissue regeneration}

Mao et al. established a multiphase scaffold mimicking cementum/dentin interface, PDL and alveolar bone by 3D printing blended polycarprolactione/hydroxyapatite $(90: 10)$ materials. By adding adequate growth factor and culturing cells, they established PDL-like tissue, the fiber of which connects from one side dentin/cementum tissue to another side bone-like tissue, which is just similar to living PDL's anatomical property (Lee et al., 2014b). Another recent 3D bioprinting research showed BMP7 was benefit for cementum formation. This research established an interface between cementum and human PDL like tissue, which is novel in combining natural tissue with artificial AM tissue in vitro. The AM scaffold was fabricated with PLGA, and then seeded human PDLSCs. After 6 weeks of culturing, they found that cementumlike layer can be successfully formed in this interface between cementum and human PDL like tissue. They also found that BMP7 helped in cementum matrix protein 1 secretion in vitro, which may be good for cementum tissue establishment (Cho et al., 2016b). 


\section{Conclusions}

432 The transition of new techniques from a novel experimental phase to be regularly available to 433 any laboratory has frequently driven step-changes in the progress of science (Hung et al., 2014b). 434 Considering the rapid development of commercial printers and open-resource software, the AM 435 technique has great potential to facilitate the next generation TE. Despite some limitations on 436 current AM scaffolds, the recently exiting advances in AM technique microstructure control, 437 porosity, porous interconnectivity, and surface modification, bioactivity in vitro and in vivo. Its 438 development may lead to a promising future to functional tissue and organ regeneration.

439 Following fields are recommended for further AM studies in craniofacial and dental TE:

440 The long-term healing effects on animal models.

441 Pre-clinic studies and clinical application on patients. This including the whole procedure from 442 the collection of defects image data of patients to the long-term morphological and functional 443 evaluation of the AM conducted patient specific scaffolds.

444 All-in-one manufacturer protocol for printing complex tissue structures with customized 445 materials, porosity, surfaces and pattern designs.

446 Tissue and (or) organ printing with live cells.

447

448

449

450

451

452

453

454

455

456

457

458

459

460

461

462

463

464

465

466

467

468

469

\section{Reference}

Alfotawei, R., Naudi, K.B., Lappin, D., Barbenel, J., Di Silvio, L., Hunter, K., McMahon, J., and Ayoub, A. 2014. The use of TriCalcium Phosphate (TCP) and stem cells for the regeneration of osteoperiosteal critical-size mandibular bony defects, an in vitro and preclinical study. J Craniomaxillofac Surg 42:863-869. 10.1016/j.jcms.2013.12.006 Barnes, C.P., Sell, S.A., Boland, E.D., Simpson, D.G., and Bowlin, G.L. 2007. Nanofiber technology: designing the next generation of tissue engineering scaffolds. Adv Drug Deliv Rev 59:1413-1433. 10.1016/j.addr.2007.04.022 Beaman, J.J., and Deckard, C.R. 1990. Selective laser sintering with assisted powder handling. Google Patents Blanquer, S.B., Sharifi, S., and Grijpma, D.W. 2012. Development of poly(trimethylene carbonate) network implants for annulus fibrosus tissue engineering. J Appl Biomater Funct Mater 10:177-184. 10.5301/JABFM.2012.10354

Bottino, M.C., Thomas, V., Schmidt, G., Vohra, Y.K., Chu, T.M., Kowolik, M.J., and Janowski, G.M. 2012. Recent advances in the development of GTR/GBR membranes for periodontal regeneration--a materials perspective. DENTAL MATERIALS 28:703-721. 10.1016/j.dental.2012.04.022

Cai, H., Azangwe, G., and Shepherd, D.E. 2005. Skin cell culture on an ear-shaped scaffold created by fused deposition modelling. Biomed Mater Eng 15:375-380.

Cao, T., Ho, K.H., and Teoh, S.H. 2003. Scaffold design and in vitro study of osteochondral coculture in a threedimensional porous polycaprolactone scaffold fabricated by fused deposition modeling. TISSUE ENGINEERING 9 Suppl 1:S103-S112. 10.1089/10763270360697012 
470 Chan, W.D., Perinpanayagam, H., Goldberg, H.A., Hunter, G.K., Dixon, S.J., Santos, G.J., and Rizkalla, A.S. 2009.

471 Tissue engineering scaffolds for the regeneration of craniofacial bone. JOURNAL OF THE CANADIAN DENTAL

472 ASSOCIATION 75:373-377.

473 Chang, J.W., Park, S.A., Park, J.K., Choi, J.W., Kim, Y.S., Shin, Y.S., and Kim, C.H. 2014. Tissue-engineered

474 tracheal reconstruction using three-dimensionally printed artificial tracheal graft: preliminary report. $A R T I F I C I A L$

475 ORGANS 38:E95-E105. 10.1111/aor.12310

476 Cho, H., Tarafder, S., Fogge, M., Kao, K., and Lee, C.H. 2016a. Periodontal ligament stem/progenitor cells with

477 protein-releasing scaffolds for cementum formation and integration on dentin surface. CONNECTIVE TISSUE

478 RESEARCH 57:488-495. 10.1080/03008207.2016.1191478

479 Cho, H., Tarafder, S., Fogge, M., Kao, K., and Lee, C.H. 2016b. Periodontal ligament stem/progenitor cells with 480 protein-releasing scaffolds for cementum formation and integration on dentin surface. CONNECTIVE TISSUE 481 RESEARCH 57:488-495. 10.1080/03008207.2016.1191478

482 Chua, C.K., Leong, K.F., Tan, K.H., Wiria, F.E., and Cheah, C.M. 2004. Development of tissue scaffolds using

483

484

485

486

487

488

489

490

491

492

493

494

495

496

497

498

499

500

501

502

503

504

505

506

507

508

509

510

511

512

513

514

515

516

517 selective laser sintering of polyvinyl alcohol/hydroxyapatite biocomposite for craniofacial and joint defects. $J$ Mater Sci Mater Med 15:1113-1121. 10.1023/B:JMSM.0000046393.81449.a5

Chung, S., Ingle, N.P., Montero, G.A., Kim, S.H., and King, M.W. 2010. Bioresorbable elastomeric vascular tissue engineering scaffolds via melt spinning and electrospinning. Acta Biomaterialia 6:1958-1967.

10.1016/j.actbio.2009.12.007

Cui, X., Breitenkamp, K., Finn, M.G., Lotz, M., and D'Lima, D.D. 2012. Direct human cartilage repair using threedimensional bioprinting technology. Tissue Eng Part A 18:1304-1312. 10.1089/ten.TEA.2011.0543

Deckard, C.R. 1991. Method and apparatus for producing parts by selective sintering. Google Patents.

Deckard, C.R., Beaman, J.J., and Darrah, J.F. 1992. Method for selective laser sintering with layerwise crossscanning. Google Patents.

Derby, B. 2012. Printing and prototyping of tissues and scaffolds. SCIENCE 338:921-926. 10.1126/science.1226340 Duan, B., and Wang, M. 2010. Customized Ca-P/PHBV nanocomposite scaffolds for bone tissue engineering: design, fabrication, surface modification and sustained release of growth factor. Journal of the Royal Society Interface 7 Suppl 5:S615-S629. 10.1098/rsif.2010.0127.focus

Duan, B., and Wang, M. 2011. Selective laser sintering and its application in biomedical engineering. $M R S$ BULLETIN 36:998-1005. 10.1557/mrs.2011.270

Fang, D., Roskies, M., Abdallah, M.N., Bakkar, M., Jordan, J., Lin, L.C., Tamimi, F., and Tran, S.D. 2017. ThreeDimensional Printed Scaffolds with Multipotent Mesenchymal Stromal Cells for Rabbit Mandibular Reconstruction and Engineering. Methods Mol Biol 1553:273-291. 10.1007/978-1-4939-6756-8_22

Fedorovich, N.E., Swennen, I., Girones, J., Moroni, L., van Blitterswijk, C.A., Schacht, E., Alblas, J., and Dhert, W.J. 2009. Evaluation of photocrosslinked Lutrol hydrogel for tissue printing applications.

BIOMACROMOLECULES 10:1689-1696. 10.1021/bm801463q

Feng, P., Niu, M., Gao, C., Peng, S., and Shuai, C. 2014. A novel two-step sintering for nano-hydroxyapatite scaffolds for bone tissue engineering. Sci Rep 4:5599. 10.1038/srep05599

Feng, P., Wei, P., Shuai, C., and Peng, S. 2014. Characterization of mechanical and biological properties of 3-D scaffolds reinforced with zinc oxide for bone tissue engineering. PLoS One 9:e87755.

10.1371/journal.pone.0087755

Fierz, F.C., Beckmann, F., Huser, M., Irsen, S.H., Leukers, B., Witte, F., Degistirici, O., Andronache, A., Thie, M., and Muller, B. 2008. The morphology of anisotropic 3D-printed hydroxyapatite scaffolds. BIOMATERIALS 29:3799-3806. 10.1016/j.biomaterials.2008.06.012

Fischer, P., Karapatis, N., Romano, V., Glardon, R., and Weber, H.P. 2002. A model for the interaction of nearinfrared laser pulses with metal powders in selective laser sintering. Applied Physics A: Materials Science \& Processing 74:467-474. 10.1007/s003390101139

Fisher, J.P., Dean, D., and Mikos, A.G. 2002. Photocrosslinking characteristics and mechanical properties of diethyl fumarate/poly(propylene fumarate) biomaterials. BIOMATERIALS 23:4333-4343.

PeerJ reviewing PDF | (2018:11:32894:2:1:NEW 9 Jun 2019) 
518 Frohlich, M., Malicev, E., Gorensek, M., Knezevic, M., and Kregar, V.N. 2007. Evaluation of rabbit auricular

519 chondrocyte isolation and growth parameters in cell culture. CELL BIOLOGY INTERNATIONAL 31:620-625.

520 10.1016/j.cellbi.2006.12.003

521 Ge, Z., Tian, X., Heng, B.C., Fan, V., Yeo, J.F., and Cao, T. 2009. Histological evaluation of osteogenesis of 3D-

522 printed poly-lactic-co-glycolic acid (PLGA) scaffolds in a rabbit model. Biomedical Materials 4:21001.

523 10.1088/1748-6041/4/2/021001

524 Gibbs, D.M., Vaezi, M., Yang, S., and Oreffo, R.O. 2014. Hope versus hype: what can additive manufacturing realistically offer trauma and orthopedic surgery? Regenerative Medicine 9:535-549. 10.2217/rme.14.20 Giordano, R.A., Wu, B.M., Borland, S.W., Cima, L.G., Sachs, E.M., and Cima, M.J. 1996. Mechanical properties of dense polylactic acid structures fabricated by three dimensional printing. J Biomater Sci Polym Ed 8:63-75. Gokuldoss, P.K., Kolla, S., and Eckert, J. 2017. Additive Manufacturing Processes: Selective Laser Melting, Electron Beam Melting and Binder Jetting-Selection Guidelines. Materials (Basel) 10. 10.3390/ma10060672 Hagandora, C.K., Gao, J., Wang, Y., and Almarza, A.J. 2013. Poly (glycerol sebacate): a novel scaffold material for temporomandibular joint disc engineering. Tissue Eng Part A 19:729-737. 10.1089/ten.tea.2012.0304

He, H.Y., Zhang, J.Y., Mi, X., Hu, Y., and Gu, X.Y. 2015. Rapid prototyping for tissue-engineered bone scaffold by 3D printing and biocompatibility study. International Journal of Clinical and Experimental Medicine 8:1177711785.

Hung, K.C., Tseng, C.S., and Hsu, S.H. 2014a. Synthesis and 3D printing of biodegradable polyurethane elastomer by a water-based process for cartilage tissue engineering applications. Advanced Healthcare Materials 3:1578-1587. 10.1002/adhm.201400018

Hung, K.C., Tseng, C.S., and Hsu, S.H. 2014b. Synthesis and 3D printing of biodegradable polyurethane elastomer by a water-based process for cartilage tissue engineering applications. Advanced Healthcare Materials 3:1578-1587.

10.1002/adhm.201400018

541 Inzana, J.A., Olvera, D., Fuller, S.M., Kelly, J.P., Graeve, O.A., Schwarz, E.M., Kates, S.L., and Awad, H.A. 2014. $3 \mathrm{D}$ printing of composite calcium phosphate and collagen scaffolds for bone regeneration. BIOMATERIALS 35:4026-4034. 10.1016/j.biomaterials.2014.01.064

Jayasinghe, S.N. 2011. Bio-electrosprays: from bio-analytics to a generic tool for the health sciences. The Analyst 136:878. 10.1039/c0an00830c

Jayasinghe, S.N. 2013. Cell electrospinning: a novel tool for functionalising fibres, scaffolds and membranes with living cells and other advanced materials for regenerative biology and medicine. The Analyst 138:2215. 10.1039/c3an36599a Jayasinghe, S.N., Qureshi, A.N., and Eagles, P.A.M. 2006. Electrohydrodynamic Jet Processing: An Advanced Electric-Field-Driven Jetting Phenomenon for Processing Living Cells. Small 2:216-219. 10.1002/smll.200500291 Jensen, J., Rolfing, J.H., Le DQ, Kristiansen, A.A., Nygaard, J.V., Hokland, L.B., Bendtsen, M., Kassem, M., Lysdahl, H., and Bunger, C.E. 2014a. Surface-modified functionalized polycaprolactone scaffolds for bone repair: in vitro and in vivo experiments. JOURNAL OF BIOMEDICAL MATERIALS RESEARCH PART A 102:2993-3003. 10.1002/jbm.a.34970

Jensen, J., Rolfing, J.H., Le DQ, Kristiansen, A.A., Nygaard, J.V., Hokland, L.B., Bendtsen, M., Kassem, M., Lysdahl, H., and Bunger, C.E. 2014b. Surface-modified functionalized polycaprolactone scaffolds for bone repair: in vitro and in vivo experiments. JOURNAL OF BIOMEDICAL MATERIALS RESEARCH PART A 102:2993-3003. 10.1002/jbm.a.34970

Kang, H.W., Lee, S.J., Ko, I.K., Kengla, C., Yoo, J.J., and Atala, A. 2016. A 3D bioprinting system to produce human-scale tissue constructs with structural integrity. NATURE BIOTECHNOLOGY 34:312-319. $10.1038 /$ nbt.3413

Khalyfa, A., Vogt, S., Weisser, J., Grimm, G., Rechtenbach, A., Meyer, W., and Schnabelrauch, M. 2007. Development of a new calcium phosphate powder-binder system for the 3D printing of patient specific implants. $J$ Mater Sci Mater Med 18:909-916. 10.1007/s10856-006-0073-2

Kim, K., Lee, C.H., Kim, B.K., and Mao, J.J. 2010. Anatomically shaped tooth and periodontal regeneration by cell homing. JOURNAL OF DENTAL RESEARCH 89:842-847. 10.1177/0022034510370803 
567 Korpela, J., Kokkari, A., Korhonen, H., Malin, M., Narhi, T., and Seppala, J. 2013. Biodegradable and bioactive

568 porous scaffold structures prepared using fused deposition modeling. J Biomed Mater Res B Appl Biomater

569 101:610-619. 10.1002/jbm.b.32863

570 Lan, P.X., Lee, J.W., Seol, Y.J., and Cho, D.W. 2009. Development of 3D PPF/DEF scaffolds using micro-

571 stereolithography and surface modification. J Mater Sci Mater Med 20:271-279. 10.1007/s10856-008-3567-2

572 Lee, C.H., Hajibandeh, J., Suzuki, T., Fan, A., Shang, P., and Mao, J.J. 2014a. Three-dimensional printed

573 multiphase scaffolds for regeneration of periodontium complex. Tissue Eng Part A 20:1342-1351.

574 10.1089/ten.TEA.2013.0386

575 Lee, C.H., Hajibandeh, J., Suzuki, T., Fan, A., Shang, P., and Mao, J.J. 2014b. Three-dimensional printed

576 multiphase scaffolds for regeneration of periodontium complex. Tissue Eng Part A 20:1342-1351.

577 10.1089/ten.TEA.2013.0386

578 Legemate, K., Tarafder, S., Jun, Y., and Lee, C.H. 2016. Engineering Human TMJ Discs with Protein-Releasing 3D-

579 Printed Scaffolds. JOURNAL OF DENTAL RESEARCH 95:800-807. 10.1177/0022034516642404

580 Leukers, B., Gulkan, H., Irsen, S.H., Milz, S., Tille, C., Schieker, M., and Seitz, H. 2005. Hydroxyapatite scaffolds

581 for bone tissue engineering made by 3D printing. J Mater Sci Mater Med 16:1121-1124. 10.1007/s10856-005-4716-

5825

583 Lohfeld, S., Cahill, S., Barron, V., McHugh, P., Durselen, L., Kreja, L., Bausewein, C., and Ignatius, A. 2012.

584 Fabrication, mechanical and in vivo performance of polycaprolactone/tricalcium phosphate composite scaffolds.

585 Acta Biomaterialia 8:3446-3456. 10.1016/j.actbio.2012.05.018

586 Lu, Y., Huang, J., Yu, G., Cardenas, R., Wei, S., Wujcik, E.K., and Guo, Z. 2016. Coaxial electrospun fibers:

587 applications in drug delivery and tissue engineering. Wiley Interdiscip Rev Nanomed Nanobiotechnol 8:654-677.

588 10.1002/wnan.1391

589 Luangphakdy, V., Walker, E., Shinohara, K., Pan, H., Hefferan, T., Bauer, T.W., Stockdale, L., Saini, S., Dadsetan,

590 M., Runge, M.B., Vasanji, A., Griffith, L., Yaszemski, M., and Muschler, G.F. 2013. Evaluation of osteoconductive

591 scaffolds in the canine femoral multi-defect model. Tissue Eng Part A 19:634-648. 10.1089/ten.TEA.2012.0289

592 Mannoor, M.S., Jiang, Z., James, T., Kong, Y.L., Malatesta, K.A., Soboyejo, W.O., Verma, N., Gracias, D.H., and

593 McAlpine, M.C. 2013. 3D printed bionic ears. NANO LETTERS 13:2634-2639. 10.1021/n14007744

594 Mazzoli, A., Germani, M., and Moriconi, G. 2007. Application of optical digitizing techniques to evaluate the shape

595 accuracy of anatomical models derived from computed tomography data. J Oral Maxillofac Surg 65:1410-1418.

$596 \quad 10.1016 /$ j.joms.2005.11.083

597 Melchels, F.P., Feijen, J., and Grijpma, D.W. 2010. A review on stereolithography and its applications in biomedical engineering. BIOMATERIALS 31:6121-6130. 10.1016/j.biomaterials.2010.04.050

600 Manufacturing Processes. Procedia CIRP 15:19-25. 10.1016/j.procir.2014.06.030

601 Meyer, U., Neunzehn, J., and Wiesmann, H.P. 2012. Computer-aided approach for customized cell-based defect

602 reconstruction. Methods Mol Biol 868:27-43. 10.1007/978-1-61779-764-4_2

603 Monteiro, N., and Yelick, P.C. 2017. Advances and perspectives in tooth tissue engineering. J Tissue Eng Regen

604 Med 11:2443-2461. 10.1002/term.2134

605 Nair, L.S., Bhattacharyya, S., and Laurencin, C.T. 2004. Development of novel tissue engineering scaffolds via

606 electrospinning. Expert Opin Biol Ther 4:659-668. 10.1517/14712598.4.5.659

607 Nikolidakis, D., Meijer, G.J., Oortgiesen, D.A., Walboomers, X.F., and Jansen, J.A. 2009. The effect of a low dose

608 of transforming growth factor beta1 (TGF-beta1) on the early bone-healing around oral implants inserted in

609 trabecular bone. BIOMATERIALS 30:94-99. 10.1016/j.biomaterials.2008.09.022

610 Nixon, A.J., Begum, L., Mohammed, H.O., Huibregtse, B., O'Callaghan, M.M., and Matthews, G.L. 2011.

611 Autologous chondrocyte implantation drives early chondrogenesis and organized repair in extensive full- and

612 partial-thickness cartilage defects in an equine model. JOURNAL OF ORTHOPAEDIC RESEARCH 29:1121-1130.

$61310.1002 /$ jor.21366 
614 Obregon, F., Vaquette, C., Ivanovski, S., Hutmacher, D.W., and Bertassoni, L.E. 2015. Three-Dimensional

615 Bioprinting for Regenerative Dentistry and Craniofacial Tissue Engineering. JOURNAL OF DENTAL RESEARCH

616 94:143S-152S. 10.1177/0022034515588885

617 Ohazama, A., Modino, S.A., Miletich, I., and Sharpe, P.T. 2004. Stem-cell-based tissue engineering of murine teeth. 618 JOURNAL OF DENTAL RESEARCH 83:518-522. 10.1177/154405910408300702

619 Park, C.H., Kim, K.H., Rios, H.F., Lee, Y.M., Giannobile, W.V., and Seol, Y.J. 2014a. Spatiotemporally controlled 620 microchannels of periodontal mimic scaffolds. JOURNAL OF DENTAL RESEARCH 93:1304-1312.

$621 \quad 10.1177 / 0022034514550716$

622 Park, C.H., Kim, K.H., Rios, H.F., Lee, Y.M., Giannobile, W.V., and Seol, Y.J. 2014b. Spatiotemporally controlled

623

624 microchannels of periodontal mimic scaffolds. JOURNAL OF DENTAL RESEARCH 93:1304-1312. $10.1177 / 0022034514550716$

Pati, F., Song, T.H., Rijal, G., Jang, J., Kim, S.W., and Cho, D.W. 2015. Ornamenting 3D printed scaffolds with cell-laid extracellular matrix for bone tissue regeneration. BIOMATERIALS 37:230-241.

10.1016/j.biomaterials.2014.10.012

628 Pautke, C., Schieker, M., Tischer, T., Kolk, A., Neth, P., Mutschler, W., and Milz, S. 2004. Characterization of osteosarcoma cell lines MG-63, Saos-2 and U-2 OS in comparison to human osteoblasts. ANTICANCER RESEARCH 24:3743-3748.

631 Poldervaart, M.T., Wang, H., van der Stok, J., Weinans, H., Leeuwenburgh, S.C., Oner, F.C., Dhert, W.J., and Alblas, J. 2013. Sustained release of BMP-2 in bioprinted alginate for osteogenicity in mice and rats. PLoS One 8:e72610. 10.1371/journal.pone.0072610

634 Przekora, A. 2019. The summary of the most important cell-biomaterial interactions that need to be considered 635 during in vitro biocompatibility testing of bone scaffolds for tissue engineering applications. Mater Sci Eng C 636 Mater Biol Appl 97:1036-1051. 10.1016/j.msec.2019.01.061

637 Qian, Y.F., Zhang, K.H., Chen, F., Ke, Q.F., and Mo, X.M. 2011. Cross-linking of gelatin and chitosan complex nanofibers for tissue-engineering scaffolds. J Biomater Sci Polym Ed 22:1099-1113. 10.1163/092050610X499447 Rai, V., Dilisio, M.F., Dietz, N.E., and Agrawal, D.K. 2017. Recent strategies in cartilage repair: A systemic review of the scaffold development and tissue engineering. JOURNAL OF BIOMEDICAL MATERIALS RESEARCH PART A 105:2343-2354. 10.1002/jbm.a.36087

642 Rasperini, G., Pilipchuk, S.P., Flanagan, C.L., Park, C.H., Pagni, G., Hollister, S.J., and Giannobile, W.V. 2015. 3D643 printed Bioresorbable Scaffold for Periodontal Repair. JOURNAL OF DENTAL RESEARCH 94:153S-157S.

$644 \quad 10.1177 / 0022034515588303$

645 Rath, S.N., Strobel, L.A., Arkudas, A., Beier, J.P., Maier, A.K., Greil, P., Horch, R.E., and Kneser, U. 2012.

646 Osteoinduction and survival of osteoblasts and bone-marrow stromal cells in 3D biphasic calcium phosphate

647 scaffolds under static and dynamic culture conditions. JOURNAL OF CELLULAR AND MOLECULAR MEDICINE

648 16:2350-2361. 10.1111/j.1582-4934.2012.01545.x

649 Ricci, J.L., Clark, E.A., Murriky, A., and Smay, J.E. 2012. Three-dimensional printing of bone repair and

650 replacement materials: impact on craniofacial surgery. JOURNAL OF CRANIOFACIAL SURGERY 23:304-308.

651 10.1097/SCS.0b013e318241dc6e

652 Sachs, E., Cima, M., and Cornie, J. 1990. Three-Dimensional Printing: Rapid Tooling and Prototypes Directly from a CAD Model. CIRP Annals 39:201-204. https://doi.org/10.1016/S0007-8506(07)61035-X

Schek, R.M., Taboas, J.M., Hollister, S.J., and Krebsbach, P.H. 2005. Tissue engineering osteochondral implants for temporomandibular joint repair. Orthodontics \& Craniofacial Research 8:313-319. 10.1111/j.1601-

6343.2005.00354.x

Shim, J.H., Kim, S.E., Park, J.Y., Kundu, J., Kim, S.W., Kang, S.S., and Cho, D.W. 2014. Three-dimensional printing of rhBMP-2-loaded scaffolds with long-term delivery for enhanced bone regeneration in a rabbit diaphyseal defect. Tissue Eng Part A 20:1980-1992. 10.1089/ten.TEA.2013.0513

Simpson, R.L., Wiria, F.E., Amis, A.A., Chua, C.K., Leong, K.F., Hansen, U.N., Chandrasekaran, M., and Lee, M.W. 2008. Development of a 95/5 poly(L-lactide-co-glycolide)/hydroxylapatite and beta-tricalcium phosphate 
662 scaffold as bone replacement material via selective laser sintering. J Biomed Mater Res B Appl Biomater 84:17-25.

$66310.1002 / \mathrm{jbm}$. b.30839

664 Skoog, S.A., Goering, P.L., and Narayan, R.J. 2014. Stereolithography in tissue engineering. J Mater Sci Mater Med 665 25:845-856. 10.1007/s10856-013-5107-y

666 Stone, K.R., Walgenbach, A.W., Abrams, J.T., Nelson, J., Gillett, N., and Galili, U. 1997. Porcine and bovine

667 cartilage transplants in cynomolgus monkey: I. A model for chronic xenograft rejection. TRANSPLANTATION

668 63:640-645.

669 Tamimi, F., Torres, J., Al-Abedalla, K., Lopez-Cabarcos, E., Alkhraisat, M.H., Bassett, D.C., Gbureck, U., and

670 Barralet, J.E. 2014. Osseointegration of dental implants in 3D-printed synthetic onlay grafts customized according to

671 bone metabolic activity in recipient site. BIOMATERIALS 35:5436-5445. 10.1016/j.biomaterials.2014.03.050

672 Temple, J.P., Hutton, D.L., Hung, B.P., Huri, P.Y., Cook, C.A., Kondragunta, R., Jia, X., and Grayson, W.L. $2014 a$.

673 Engineering anatomically shaped vascularized bone grafts with hASCs and 3D-printed PCL scaffolds. JOURNAL

674 OF BIOMEDICAL MATERIALS RESEARCH PART A 102:4317-4325. 10.1002/jbm.a.35107

675 Temple, J.P., Hutton, D.L., Hung, B.P., Huri, P.Y., Cook, C.A., Kondragunta, R., Jia, X., and Grayson, W.L. 2014 b.

676 Engineering anatomically shaped vascularized bone grafts with hASCs and 3D-printed PCL scaffolds. JOURNAL

677 OF BIOMEDICAL MATERIALS RESEARCH PART A 102:4317-4325. 10.1002/jbm.a.35107

678 Tong, H.W., Wang, M., and Lu, W.W. 2012. Electrospinning and evaluation of PHBV-based tissue engineering

679 scaffolds with different fibre diameters, surface topography and compositions. J Biomater Sci Polym Ed 23:779-806.

$68010.1163 / 092050611$ X560708

681 Torres, J., Tamimi, F., Alkhraisat, M.H., Prados-Frutos, J.C., Rastikerdar, E., Gbureck, U., Barralet, J.E., and Lopez-

682 Cabarcos, E. 2011. Vertical bone augmentation with 3D-synthetic monetite blocks in the rabbit calvaria. JOURNAL

683 OF CLINICAL PERIODONTOLOGY 38:1147-1153. 10.1111/j.1600-051X.2011.01787.x

684 Torres, K., Staskiewicz, G., Sniezynski, M., Drop, A., and Maciejewski, R. 2011. Application of rapid prototyping

685 techniques for modelling of anatomical structures in medical training and education. Folia Morphol (Warsz) 70:1-4.

686 Townsend-Nicholson, A., and Jayasinghe, S.N. 2006. Cell Electrospinning: a Unique Biotechnique for

687 Encapsulating Living Organisms for Generating Active Biological Microthreads/Scaffolds.

688 BIOMACROMOLECULES 7:3364-3369. 10.1021/bm060649h

689 Van Bael, S., Desmet, T., Chai, Y.C., Pyka, G., Dubruel, P., Kruth, J.P., and Schrooten, J. 2013. In vitro cell-

690 biological performance and structural characterization of selective laser sintered and plasma surface functionalized

691 polycaprolactone scaffolds for bone regeneration. Mater Sci Eng C Mater Biol Appl 33:3404-3412.

$69210.1016 /$ j.msec.2013.04.024

693 Von der Mark, K., Gauss, V., von der Mark, H., and Muller, P. 1977. Relationship between cell shape and type of

694 collagen synthesised as chondrocytes lose their cartilage phenotype in culture. NATURE 267:531-532.

695 Walter, S.G., Ossendorff, R., and Schildberg, F.A. 2019. Articular cartilage regeneration and tissue engineering

696 models: a systematic review. Arch Orthop Trauma Surg 139:305-316. 10.1007/s00402-018-3057-z

697 Wang, X., Schroder, H.C., Feng, Q., Draenert, F., and Muller, W.E. 2013. The deep-sea natural products, biogenic

698 polyphosphate (Bio-PolyP) and biogenic silica (Bio-Silica), as biomimetic scaffolds for bone tissue engineering:

699 fabrication of a morphogenetically-active polymer. Marine Drugs 11:718-746. 10.3390/md11030718

700 Wang, X., Schroder, H.C., Grebenjuk, V., Diehl-Seifert, B., Mailander, V., Steffen, R., Schlossmacher, U., and

701 Muller, W.E. 2014. The marine sponge-derived inorganic polymers, biosilica and polyphosphate, as

702 morphogenetically active matrices/scaffolds for the differentiation of human multipotent stromal cells: potential

703 application in 3D printing and distraction osteogenesis. Marine Drugs 12:1131-1147. 10.3390/md12021131

704 Warren, S.M., Fong, K.D., Chen, C.M., Loboa, E.G., Cowan, C.M., Lorenz, H.P., and Longaker, M.T. 2003. Tools

705 and techniques for craniofacial tissue engineering. TISSUE ENGINEERING 9:187-200.

$706 \quad 10.1089 / 107632703764664666$

707 Williams, J.M., Adewunmi, A., Schek, R.M., Flanagan, C.L., Krebsbach, P.H., Feinberg, S.E., Hollister, S.J., and

708 Das, S. 2005. Bone tissue engineering using polycaprolactone scaffolds fabricated via selective laser sintering.

709 BIOMATERIALS 26:4817-4827. 10.1016/j.biomaterials.2004.11.057

Peer] reviewing PDF | (2018:11:32894:2:1:NEW 9 Jun 2019) 
710 Xu, T., Binder, K.W., Albanna, M.Z., Dice, D., Zhao, W., Yoo, J.J., and Atala, A. 2013. Hybrid printing of

711 mechanically and biologically improved constructs for cartilage tissue engineering applications. Biofabrication

712 5:15001. 10.1088/1758-5082/5/1/015001

713 Xue, S.H., Lv, P.J., Wang, Y., Zhao, Y., and Zhang, T. 2013. [Three dimensional bioprinting technology of human 714 dental pulp cells mixtures]. Beijing Da Xие Xuе Bao Yi Xue Ban 45:105-108.

715 Yao, Q., Wei, B., Liu, N., Li, C., Guo, Y., Shamie, A.N., Chen, J., Tang, C., Jin, C., Xu, Y., Bian, X., Zhang, X.,

716 and Wang, L. 2015. Chondrogenic regeneration using bone marrow clots and a porous polycaprolactone-

717 hydroxyapatite scaffold by three-dimensional printing. Tissue Eng Part A 21:1388-1397.

718 10.1089/ten.TEA.2014.0280

719 Yen, H.J., Hsu, S.H., Tseng, C.S., Huang, J.P., and Tsai, C.L. 2009. Fabrication of precision scaffolds using liquidfrozen deposition manufacturing for cartilage tissue engineering. Tissue Eng Part A 15:965-975. 10.1089/ten.tea.2008.0090

722 Yoshioka, T., Mishima, H., Sakai, S., and Uemura, T. 2013. Long-Term Results of Cartilage Repair after Allogeneic 723 Transplantation of Cartilaginous Aggregates Formed from Bone Marrow-Derived Cells for Large Osteochondral 724 Defects in Rabbit Knees. Cartilage 4:339-344. 10.1177/1947603513494003

725 Zamani, R., Aval, S.F., Pilehvar-Soltanahmadi, Y., Nejati-Koshki, K., and Zarghami, N. 2018. Recent Advances in 726 Cell Electrospining of Natural and Synthetic Nanofibers for Regenerative Medicine. Drug Res (Stuttg) 68:425-435. $727 \quad 10.1055 / \mathrm{s}-0043-125314$

728 Zhou, W.Y., Lee, S.H., Wang, M., Cheung, W.L., and Ip, W.Y. 2008. Selective laser sintering of porous tissue engineering scaffolds from poly(L: -lactide)/carbonated hydroxyapatite nanocomposite microspheres. J Mater Sci Mater Med 19:2535-2540. 10.1007/s10856-007-3089-3

731 Zopf, D.A., Mitsak, A.G., Flanagan, C.L., Wheeler, M., Green, G.E., and Hollister, S.J. 2015. Computer aided732 designed, 3-dimensionally printed porous tissue bioscaffolds for craniofacial soft tissue reconstruction. Otolaryngol Head Neck Surg 152:57-62. 10.1177/0194599814552065

734

735 


\section{Figure 1}

Four kinds of typical AM printers.

A schematic of SLS: The fabrication chamber is settled at the base, filling with tightly compacted plastic powder. When the laser beam moves under the guidance of the scanner system and computer code, precisely shaped monolayer is printed by causing the temperature to rise above the melting point of plastic powder. B schematic of SLA: A computer-controlled laser beam moves and cures the top liquid resin by photopolymerisation. The polymerized resin will adhere to a building platform for support. After finishing the first layer, the building platform drops a defined distance under the liquid surface and the laser repeats the above steps to cure a second layer. C schematic of FFF: Thermoplastic polymeric filament is extruded as the “ink" from a high temperature nozzle (typically $95^{\circ} \mathrm{C}-230^{\circ} \mathrm{C}$ ) because of a solid-semiliquid state transition. After printing the pattern of the first layer on a surface, either the nozzle rises, or the platform descends in the Z-axis direction at a thickness of a mono by the control of computer. The process is repeated until structure generation is complete. D schematic of binder jetting: Liquid binder is printed as ink onto powder container. Then a new consecutive solid thin layer of free powder will be put on the binder. This printing process repeats until finishing the work.
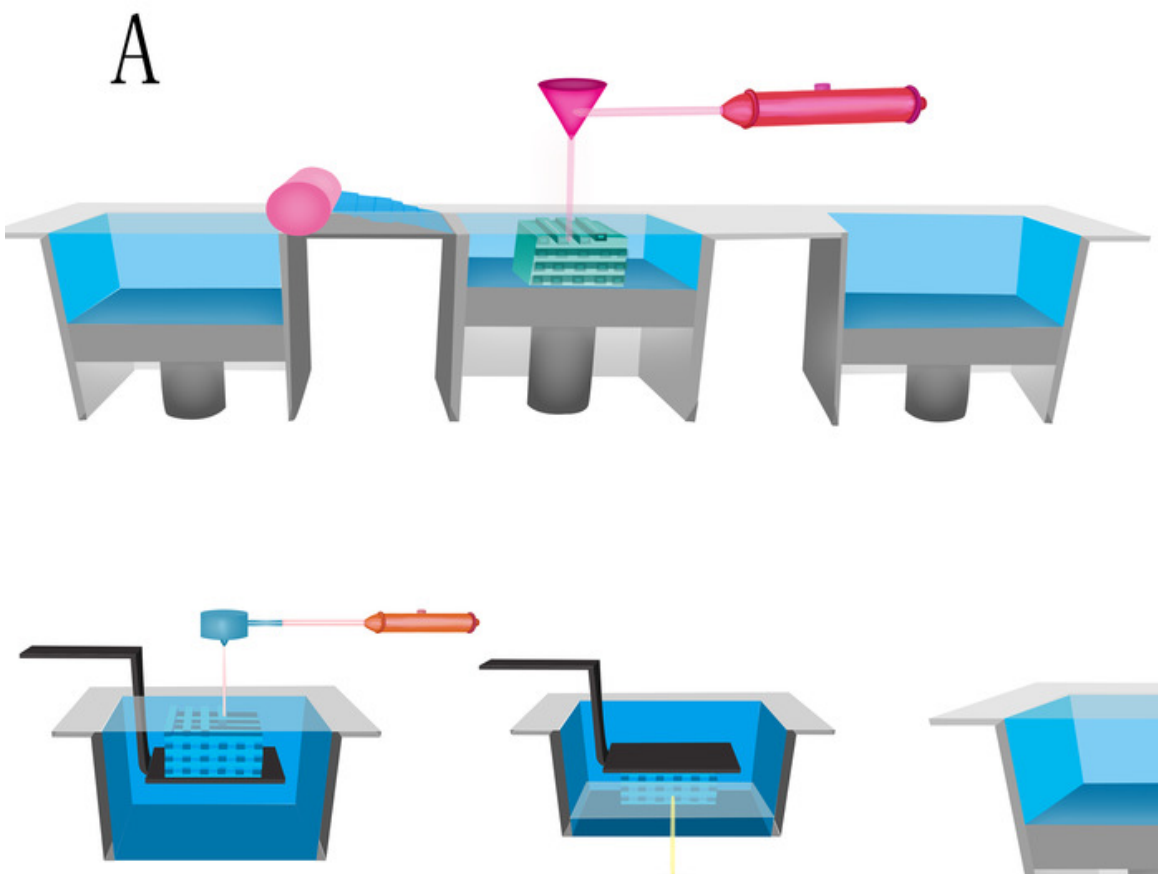

B
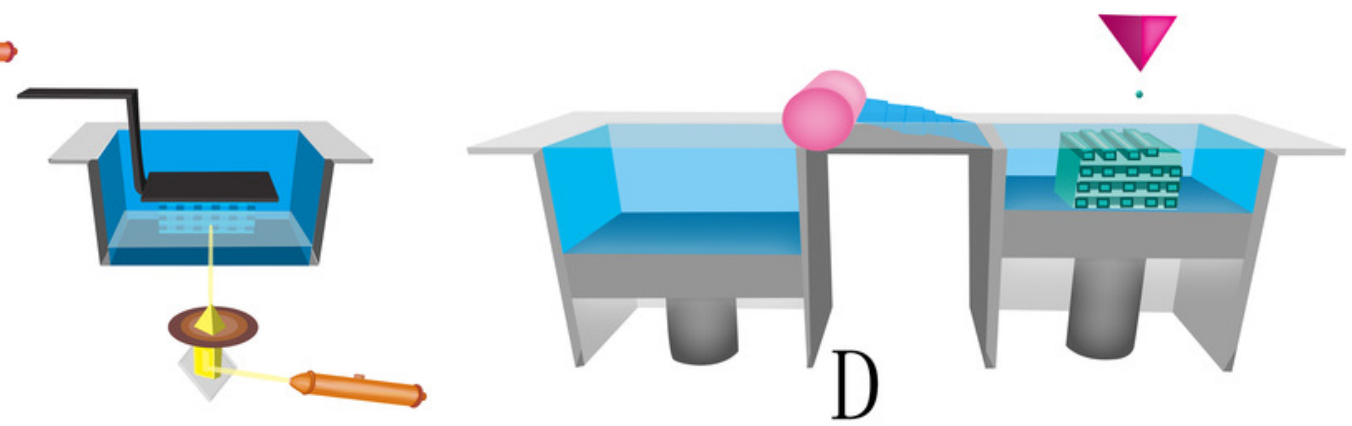


\section{Figure 2}

Chart of the different working steps done in this investigation.

Chart of the different working steps done in this investigation. (A-C) Fabrication of the scaffolds .(D-F) cell cultivation .(G-I) implantation of cell-loaded scaffolds and healing. Histology of bone regeneration 3 days after implantation (arrows mark regions of mineralized matrix; original magnification $\mathrm{X10}$ ) (J). Defect site 30 days post implantation (arrows mark regions of mineralized matrix; original magnification X10) (K). (by U. Meyer, et. al., copyright authorized by publisher). 


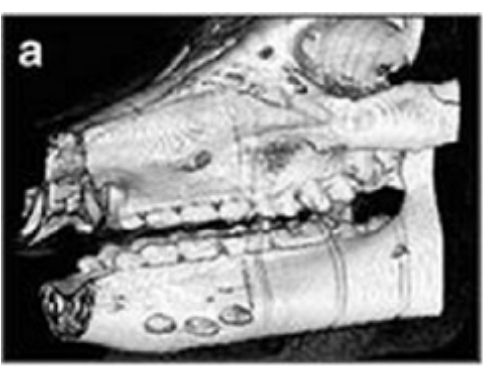

Three-dimensional view of a mandibular defect site

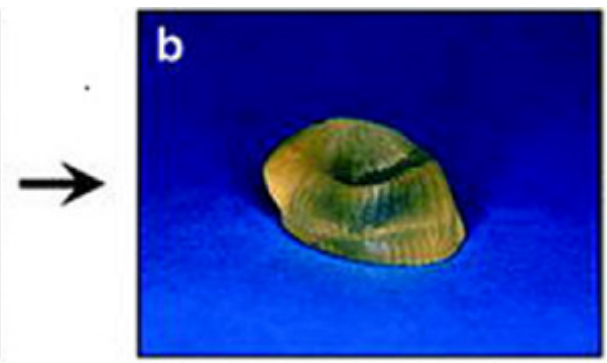

Stereolithographic model of the defect site
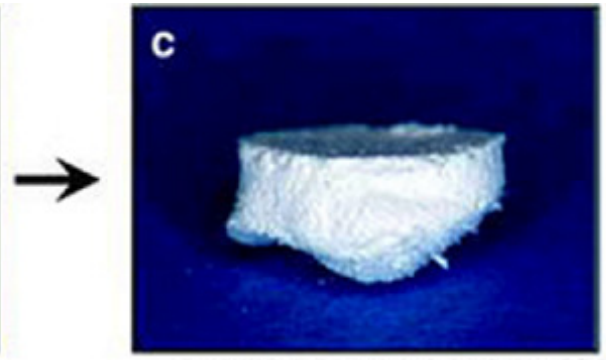

Individual PLAMPA scaffold
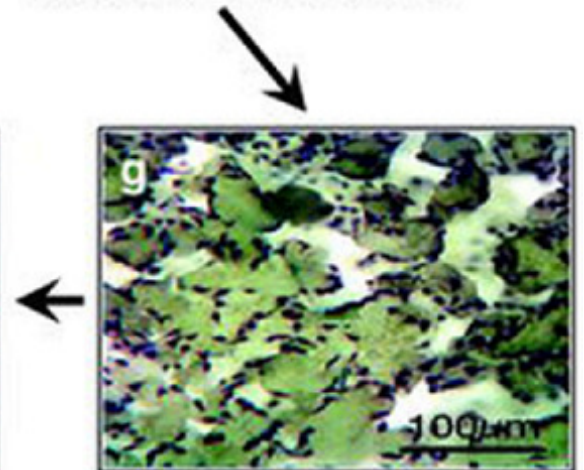

Three-dimensional image of mandiblar body after 4 weeks

Surgical implantation of the scaffold

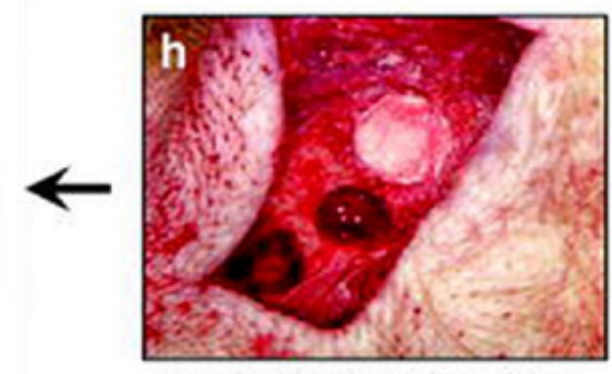

Scaffold with cultivated cells

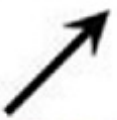

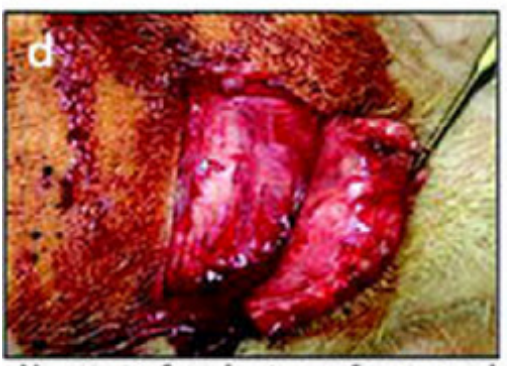

Harvest of periosteum from porcine calvarium

j

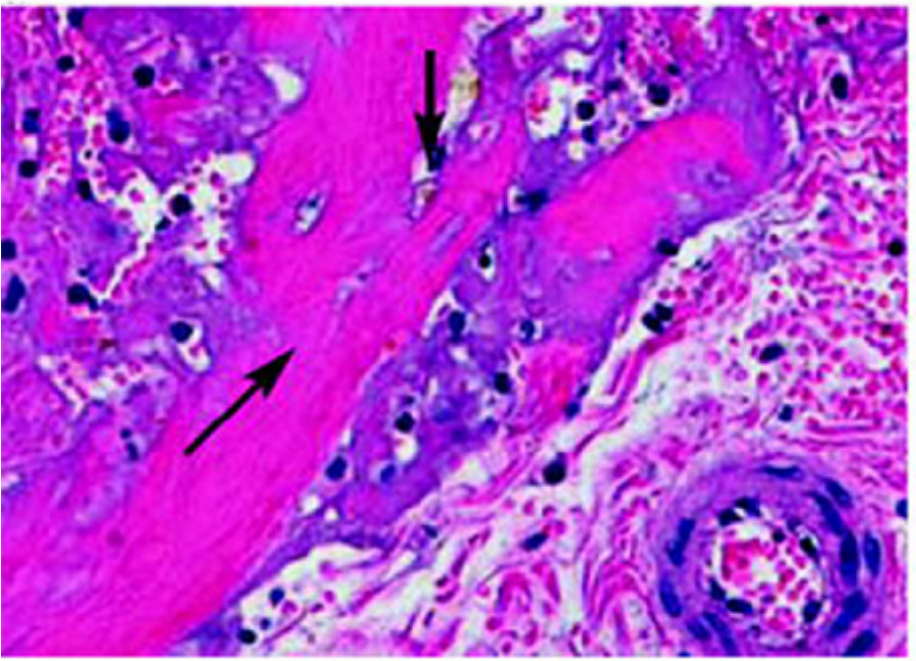

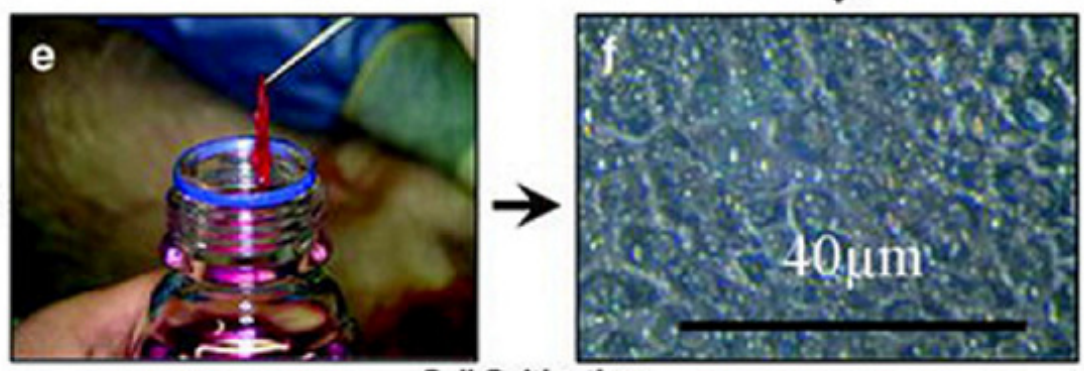

Cell Cultivation

k

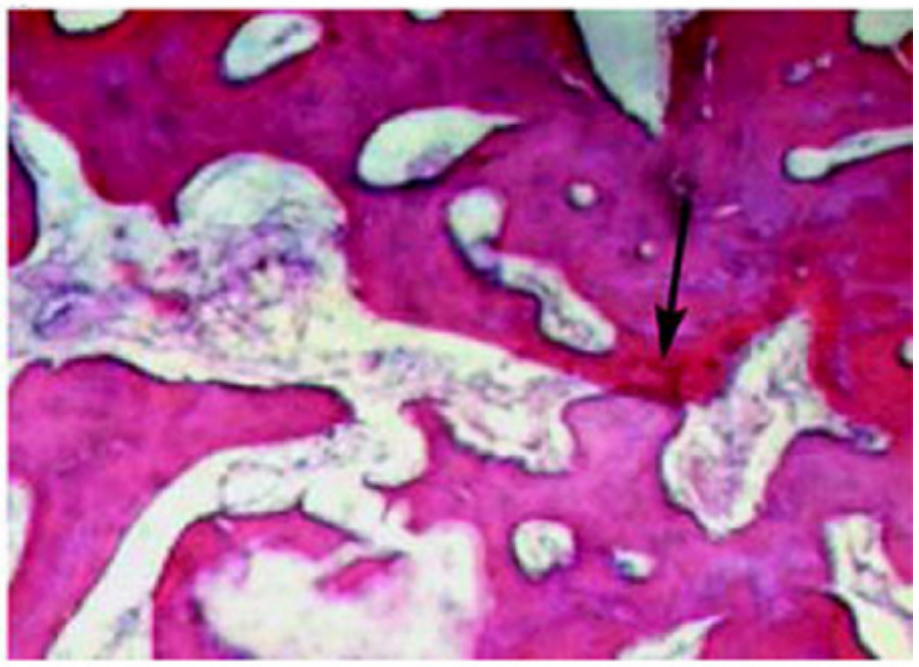




\section{Figure 3}

Image-based design allowing creation of defect site- specific scaffolds.

The revised legend: Image-based design allowing creation of defect site-specific scaffolds. The patient image (A) is used in conjunction with appropriate microstructure architecture to create the design for the implant (B). This design can then be produced using solid free-form fabrication, as in this prototype constructed from a single polymeric material (C). Scaffolds were demineralized prior to sectioning, resulting in empty areas (marked with*) that were previously occupied by HA. Safranin $O$ and fast green staining showed a large area of pink-stained cartilage (arrow) in the polymer sponge, in contact with the green-brown-stained bone that formed in the ceramic phase (E). Small pockets of cartilage were also observed within the pores of the ceramic phase of the scaffold (E, arrow). Hematoxylin and eosin staining of the ceramic phase showed the formation of bone $(F$, arrow) with marrow space within the pores of the HA. The assembled composite: the upper polymer phase (white) and the lower ceramic phase (blue) are transversed by the two PLA struts, one of which is visible on the front of the construct (G). $\odot$ John Wiley \& Sons (by R.M. Schek, et al., copyright authorized by publisher). 

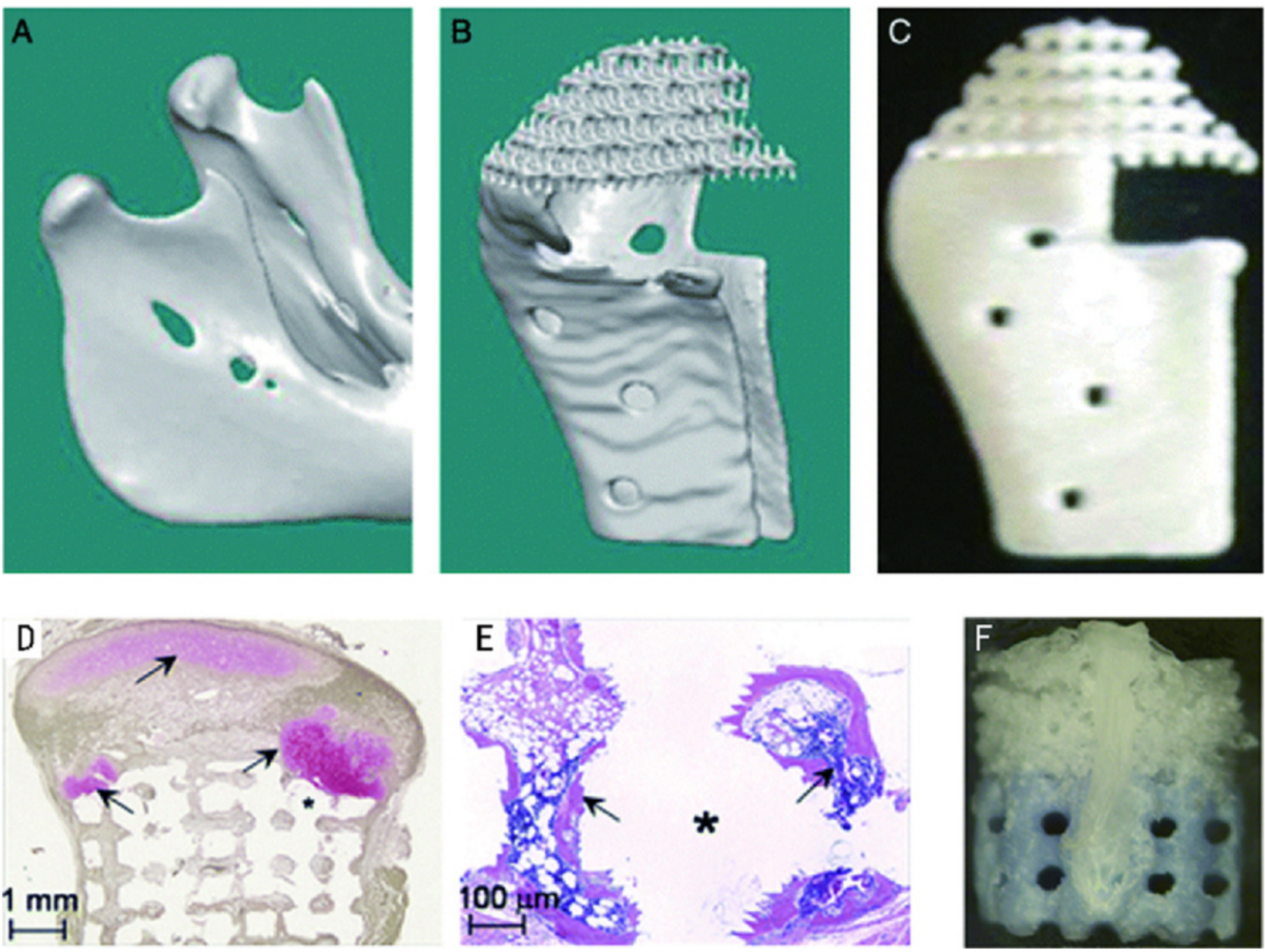


\section{Figure 4}

Design and fabrication of anatomically shaped human and rat tooth scaffolds by 3D bioprinting.

Design and fabrication of anatomically shaped human and rat tooth scaffolds by 3D bioprinting. Anatomic shape of the rat mandibular central incisor (A) and human mandibular first molar (B) were used for 3D reconstruction and bioprinting of a hybrid scaffold of poly-e-caprolactone and hydroxyapatite, with $200-\mu \mathrm{m}$ microstrands and interconnecting microchannels (diam., $200 \mu \mathrm{m}$ ), which serve as conduits for cell homing and angiogenesis (C,D). A blended cocktail of stromal-derived factor-1 (100 ng/mL) and bone morphogenetic protein-7 (100 ng/mL) was delivered in $2 \mathrm{mg} / \mathrm{mL}$ neutralized type I collagen solution and infused in scaffold microchannels for rat incisor scaffold (E) and human molar scaffold (F), followed by gelation. (G) In human mandibular molar scaffolds, cells populated scaffold microchannels without growthfactor delivery. (H) Combined SDF1 and BMP7 delivery induced substantial cell homing into microchannels. (I) Combined SDF1 and BMP7 delivery homed significantly more cells into the microchannels than without growth-factor delivery $(p<0.01 ; N=11)$. (J) Combined SDF1 and BMP7 delivery elaborated significantly more blood vessels than without growth-factor delivery $(p<0.05 ; N=11)$. (K,L) Mineral tissue in isolated areas in microchannels adjacent to blood vessels and abundant cells, and confirmed by von Kossa staining. (M) Tissue sections from coronal, middle, and two root portions of human molar scaffolds were quantified for cell density and angiogenesis. S, scaffold; GF, growth factor(s). Scale: $100 \mu$ m. (c) SAGE Publications (by K. Kim, et al., copyright authorized by publisher).
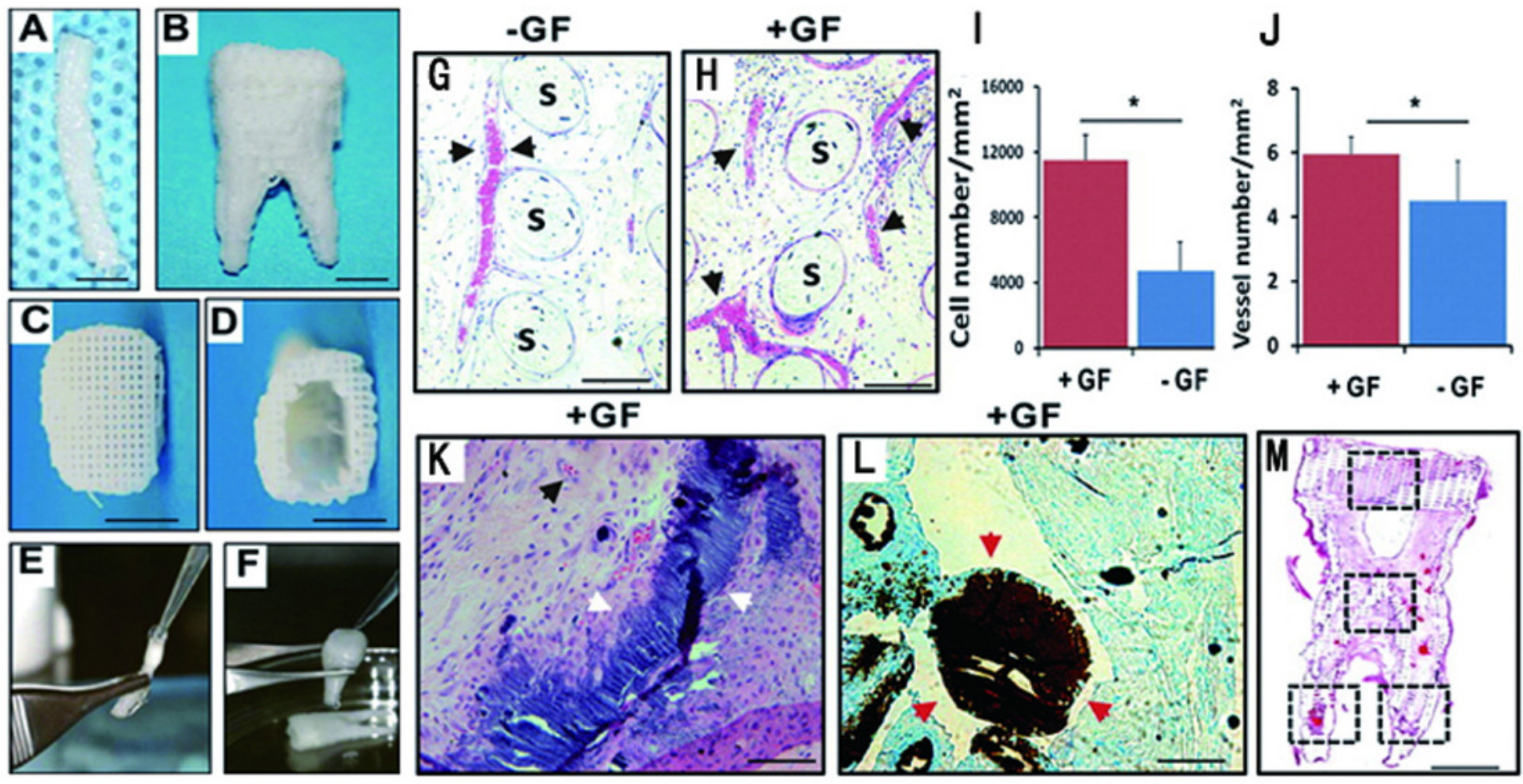


\section{Table $\mathbf{1}$ (on next page)}

Comparison of various printed bone scaffolds in several in vitro and in vivo studies.

Comparison of various printed bone scaffolds in several in vitro and in vivo studies 


\begin{tabular}{|c|c|c|c|c|c|c|}
\hline $\begin{array}{l}\text { Author } \\
\text { s }\end{array}$ & $\begin{array}{l}\text { Materi } \\
\text { als }\end{array}$ & $\begin{array}{l}\text { Strateg } \\
\text { ies }\end{array}$ & $\begin{array}{l}\text { Eviden } \\
\text { ce }\end{array}$ & $\begin{array}{l}\text { Model of } \\
\text { study }\end{array}$ & Periods & Effects \\
\hline $\begin{array}{l}\text { Leukers } \\
\text { et al., } \\
2005\end{array}$ & $\mathrm{HA}$ & $\begin{array}{l}\mathrm{DP}+ \\
\text { Sintered }\end{array}$ & In vitro & MC3T3-E1 & 7 days & $\begin{array}{l}\text { The cells proliferated deep } \\
\text { into the structure forming } \\
\text { close contact HA granules. }\end{array}$ \\
\hline $\begin{array}{l}\text { William } \\
\text { s et al., } \\
2005\end{array}$ & PCL & SLS & $\begin{array}{l}\text { In vitro } \\
\text { In vivo }\end{array}$ & $\begin{array}{l}\text { BMP7 } \\
\text { transduced } \\
\text { HGF, } \\
\text { Mice }\end{array}$ & 4 weeks & $\begin{array}{l}\text { SLS printed PCL scaffolds } \\
\text { enhance bone tissue in- } \\
\text { growth. }\end{array}$ \\
\hline $\begin{array}{l}\text { Mapili } \\
\text { et al., } \\
2005\end{array}$ & $\begin{array}{l}\text { PEGD } \\
\text { MA }\end{array}$ & SLA & In vitro & $\begin{array}{l}\text { Acryl-PEG- } \\
\text { RGD }\end{array}$ & $\begin{array}{l}24 \\
\text { hours }\end{array}$ & $\begin{array}{l}\text { Heparan sulfate allows } \\
\text { efficient cell attachment } \\
\text { and spatial localization of } \\
\text { growth factors. }\end{array}$ \\
\hline $\begin{array}{l}\text { Arcaute } \\
\text { et al., } \\
2006\end{array}$ & $\begin{array}{l}\text { PEGD } \\
\text { MA }\end{array}$ & SLA & In vitro & $\begin{array}{l}\text { Human dermal } \\
\text { fibroblasts }\end{array}$ & $\begin{array}{l}24 \\
\text { hours }\end{array}$ & $\begin{array}{l}\text { Cell viability reaches at } \\
\text { least } 87 \% \text { at } 2 \text { hours and } \\
24 \text { hours following } \\
\text { fabrication. }\end{array}$ \\
\hline $\begin{array}{l}\text { Li et al., } \\
2007\end{array}$ & $\begin{array}{l}\text { epoxy } \\
\text { resin } \\
\text { (SL, } \\
7560, \\
\text { Huntsm } \\
\text { an); } \\
\mathrm{CPC(sc} \\
\text { affold) }\end{array}$ & SLA & In vitro & $\mathrm{OB}$ & 7 days & $\begin{array}{l}\text { Negative molds were } \\
\text { generated by SLA. Cell } \\
\text { density increased. }\end{array}$ \\
\hline $\begin{array}{l}\text { Khalyfa } \\
\text { et al., } \\
2007\end{array}$ & $\begin{array}{l}\mathrm{TCP} / \mathrm{TT} \\
\mathrm{CP}\end{array}$ & $\begin{array}{l}3 \mathrm{DP}, \\
\text { Sintered } \\
\text { polymer } \\
\text { infiltrati } \\
\text { on }\end{array}$ & In vitro & MC3T3-E1 & 3 weeks & $\begin{array}{l}\text { Objects with high } \\
\text { compression strengths are } \\
\text { obtained without sintering. } \\
\text { Cell proliferation and } \\
\text { osteogenic differentiation } \\
\text { are achieved. }\end{array}$ \\
\hline $\begin{array}{l}\text { Goodrid } \\
\text { ge et } \\
\text { al., }\end{array}$ & & SLS & In vivo & Rabbit tibiae & 4 weeks & $\begin{array}{l}\text { Bone was seen to have } \\
\text { grown into the porous } \\
\text { structure of the laser- }\end{array}$ \\
\hline
\end{tabular}




\begin{tabular}{|c|c|c|c|c|c|c|}
\hline 2007 & & & & & & sintered parts. \\
\hline $\begin{array}{l}\text { Habibo } \\
\text { vic et } \\
\text { al., } \\
2008\end{array}$ & $\begin{array}{l}\text { Biocera } \\
\text { mic }\end{array}$ & $3 \mathrm{DP}$ & In vivo & $\begin{array}{l}12 \text { adult Dutch } \\
\text { milk goats }\end{array}$ & $\begin{array}{l}12 \\
\text { weeks }\end{array}$ & $\begin{array}{l}\text { Bone formation within the } \\
\text { channels of both monetite } \\
\text { and brushite, indicate } \\
\text { osteoinductivity of the } \\
\text { materials. }\end{array}$ \\
\hline $\begin{array}{l}\text { Lee et } \\
\text { al., } \\
2008\end{array}$ & $\begin{array}{l}\mathrm{PPF} / \mathrm{DE} \\
\mathrm{F}\end{array}$ & SLA & In vitro & Fibroblasts & 1 week & $\begin{array}{l}\text { Cells were adhering to and } \\
\text { had proliferated at the top } \\
\text { surface of the scaffold. }\end{array}$ \\
\hline $\begin{array}{l}\text { Geffre } \\
\text { et al., } \\
2009\end{array}$ & $\begin{array}{l}\text { Polyme } \\
\text { r (NG) }\end{array}$ & FDM & In vivo & $\begin{array}{l}\text { Femoral } \\
\text { condyles } \\
\text { (animal NG) }\end{array}$ & $\begin{array}{l}5 \\
\text { months }\end{array}$ & $\begin{array}{l}\text { Biomimetic porous design } \\
\text { largely enhances bone } \\
\text { ingrowth. }\end{array}$ \\
\hline $\begin{array}{l}\text { Lan et } \\
\text { al., } \\
2009\end{array}$ & $\begin{array}{l}\mathrm{PPF} / \mathrm{DE} \\
\mathrm{F}\end{array}$ & SLA & In vitro & MC3T3-E1 & 2 weeks & $\begin{array}{l}\text { MC3T3 pre-osteoblast } \\
\text { compatibility with } \\
\text { PPF/DEF scaffolds is } \\
\text { greatly enhanced with } \\
\text { biomimetic apatite coating }\end{array}$ \\
\hline $\begin{array}{l}\text { Fedorov } \\
\text { ich et } \\
\text { al., } \\
2009\end{array}$ & $\begin{array}{l}\text { photose } \\
\text { nsitive } \\
\text { hydroge } \\
1 \\
\text { (Lutrol) }\end{array}$ & $\begin{array}{l}\text { Hydrog } \\
\text { el } \\
\text { extrusio } \\
\text { n, UV }\end{array}$ & In vitro & MSCs & 3 weeks & $\begin{array}{l}\text { MSCs embedded in } \\
\text { photopolymerizable } \\
\text { Lutrol-TP gels remain } \\
\text { viable of } 60 \% \text { and keep } \\
\text { potential of osteogenic } \\
\text { differentiation. }\end{array}$ \\
\hline $\begin{array}{l}\text { Zigang } \\
\text { et al., } \\
2009\end{array}$ & $\begin{array}{l}\text { PLGA/ } \\
\text { PVA }\end{array}$ & $3 \mathrm{DP}$ & In vitro & $\begin{array}{l}\text { Human } \\
\text { Osteoblasts } \\
\text { CRL-11372 }\end{array}$ & 3 weeks & $\begin{array}{l}\text { Expression of ALP and } \\
\text { osteonectin remain stable } \\
\text { whilst collagen type I and } \\
\text { osteopontin decrease. }\end{array}$ \\
\hline $\begin{array}{l}\text { Ge et } \\
\text { al., } \\
2009\end{array}$ & $\begin{array}{l}\text { PLGA/ } \\
\text { PVA }\end{array}$ & $3 \mathrm{DP}$ & In vivo & $\begin{array}{l}\text { Rabbit: } \\
1 \text { intra- } \\
\text { periosteum } \\
\text { model. } \\
2 \text { bone defect } \\
\text { of Ilium. }\end{array}$ & $\begin{array}{l}24 \\
\text { weeks }\end{array}$ & $\begin{array}{l}\text { In both models, the } \\
\text { implanted scaffolds } \\
\text { facilitated new bone tissue } \\
\text { formation and maturation. }\end{array}$ \\
\hline Duan \& & Custom & SLS & In vitro & $\mathrm{SaOS}-2$ & 3 weeks & Affinity of rhBMP2 on \\
\hline
\end{tabular}




\begin{tabular}{|c|c|c|c|c|c|c|}
\hline $\begin{array}{l}\text { Wang, } \\
2010\end{array}$ & $\begin{array}{l}\text { ized } \\
\mathrm{Ca}- \\
\mathrm{P} / \mathrm{PHB} \\
\mathrm{V}\end{array}$ & & & $\begin{array}{l}\text { C3H10T1/2 } \\
\text { cells }\end{array}$ & & $\begin{array}{l}\text { immobilized heparin } \\
\text { facilitated the osteogenic } \\
\text { differentiation of } \\
\text { C3H10T1/2 cells during } \\
\text { the whole period. }\end{array}$ \\
\hline $\begin{array}{l}\text { Warnke } \\
\text { et al., } \\
2010\end{array}$ & $\begin{array}{l}\text { TCP, } \\
\text { HAP }\end{array}$ & $\begin{array}{l}3 \mathrm{DP}+ \\
\text { Sintered }\end{array}$ & In vitro & $\begin{array}{l}\text { Primary } \\
\text { human } \\
\text { osteoblasts. }\end{array}$ & 1 week & $\begin{array}{l}\text { Superior biocompatibility } \\
\text { of HAP scaffolds to } \\
\text { BioOss@ is proved, while } \\
\text { BioOss@ is more } \\
\text { compatible than TCP. }\end{array}$ \\
\hline $\begin{array}{l}\text { Melchel } \\
\text { s et al., } \\
2010\end{array}$ & $\begin{array}{l}\operatorname{poly}(\mathrm{D}, \\
\text { L- } \\
\text { lactide }) \\
\text { resin }\end{array}$ & SLA & In vitro & MC3T3 & 11 days & $\begin{array}{l}\text { Pre-osteoblasts showed } \\
\text { good adherence to these } \\
\text { photo-crosslinked } \\
\text { networks. }\end{array}$ \\
\hline $\begin{array}{l}\text { Detsch } \\
\text { et al., } \\
2011\end{array}$ & $\begin{array}{l}\text { HA, } \\
\text { TCP, } \\
\text { HA/TC } \\
\text { P }\end{array}$ & $3 \mathrm{DP}$ & In vitro & $\begin{array}{l}\text { RAW } 264.7 \\
\text { cell line }\end{array}$ & & $\begin{array}{l}21 \text { days The results show } \\
\text { that osteoclast-like cells } \\
\text { were able to resorb } \\
\text { calcium phosphate } \\
\text { surfaces consisting of } \\
\text { granules. }\end{array}$ \\
\hline $\begin{array}{l}\text { Torres } \\
\text { et al., } \\
2011\end{array}$ & $\begin{array}{l}\text { b-TCP } \\
\text { powder }\end{array}$ & 3DP & In vivo & $\begin{array}{l}\text { Rabbit calvaria } \\
\text { vertical bone } \\
\text { augmentation }\end{array}$ & 8 weeks & $\begin{array}{l}\text { Synthetic onlay blocks } \\
\text { achieve vertical bone } \\
\text { augmentations as as high } \\
\text { as } 4.0 \mathrm{~mm} \text {. }\end{array}$ \\
\hline $\begin{array}{l}\text { Rath et } \\
\text { al., } \\
2012\end{array}$ & $\begin{array}{l}\text { biphasic } \\
\text { calcium } \\
\text { phospha } \\
\text { te } \\
(\mathrm{BCP})\end{array}$ & $\begin{array}{l}3 \mathrm{DP}+ \\
\text { Sintered }\end{array}$ & In vitro & $\begin{array}{l}\text { OB } \\
\text { BMSC }\end{array}$ & $\begin{array}{l}3 \\
\text { weeks, } \\
6 \text { weeks }\end{array}$ & $\begin{array}{l}\text { Application of a bioreactor } \\
\text { system increases the } \\
\text { proliferation and } \\
\text { differentiation potential }\end{array}$ \\
\hline $\begin{array}{l}\text { Blanque } \\
\text { r et al., } \\
2012\end{array}$ & $\begin{array}{l}\text { PDLLA } \\
3- \\
\text { FAME/ }\end{array}$ & SLA & In vitro & MC3T3 & $\mathrm{NG}$ & $\begin{array}{l}\text { Mouse preosteoblasts } \\
\text { readily attach and spread } \\
\text { onto porous structures }\end{array}$ \\
\hline
\end{tabular}




\begin{tabular}{|c|c|c|c|c|c|c|}
\hline & NVP & & & & & $\begin{array}{l}\text { with the well-defined } \\
\text { gyroid architectures by } \\
\text { SLA. }\end{array}$ \\
\hline $\begin{array}{l}\text { Korpela } \\
\text { et al., } \\
2013\end{array}$ & $\begin{array}{l}\text { PCL/bi } \\
\text { oactive } \\
\text { glass(B } \\
\text { AG), } \\
\text { PLA }\end{array}$ & FDM & In vitro & Fibroblasts & 2 weeks & $\begin{array}{l}\text { FDM printed PLA has } \\
\text { better cell friendly surface } \\
\text { than PCL and PCL/BAG. }\end{array}$ \\
\hline $\begin{array}{l}\text { Luangp } \\
\text { hakdy } \\
\text { et al., } \\
2013\end{array}$ & $\begin{array}{l}\text { PLGA } \\
\text { TCP } \\
\text { PPF } \\
\text { HA } \\
\text { TyrPC } \\
\text { MCA }\end{array}$ & $\begin{array}{l}3 \text { DP VS } \\
\text { SLA } \\
\text { VS } \\
\text { PL VS } \\
\text { CM }\end{array}$ & In vivo & $\begin{array}{l}\text { Canine } \\
\text { Femoral } \\
\text { Multi-Defect } \\
\text { Model }\end{array}$ & 4 weeks & $\begin{array}{l}\text { TyrPCPL/TCP and } \\
\text { PPF4SLA/HAPLGA Dip } \\
\text { are better in } \\
\text { biocompatibility than } \\
\text { PLGA and PLCL } \\
\text { scaffolds. MCA remains } \\
\text { the best. }\end{array}$ \\
\hline $\begin{array}{l}\text { Wang } \\
\text { et al., } \\
2013\end{array}$ & $\begin{array}{l}\text { biogeni } \\
\text { c } \\
\text { polypho } \\
\text { sphate } \\
\text { (bio- } \\
\text { polyP) } \\
\text { and } \\
\text { biogeni } \\
\text { c silica } \\
\text { (bio- } \\
\text { silica) }\end{array}$ & $\begin{array}{l}\mathrm{SFF} / \\
\text { indirect } \\
3 \mathrm{DP} / \\
\text { direct } \\
3 \mathrm{DP}\end{array}$ & In vitro & $\begin{array}{l}\text { SaOS- } 2 \text { cells, } \\
\text { RAW } 264.7 \\
\text { cells }\end{array}$ & 10 days & $\begin{array}{l}\text { Bio-silica ans bio-polyP } \\
\text { increase release of BMP2 } \\
\text { while bio-polyP inhibits } \\
\text { osteoclasts activity. }\end{array}$ \\
\hline $\begin{array}{l}\text { Van } \\
\text { Bael et } \\
\text { al., } \\
2013\end{array}$ & PCL & SLS & In vitro & hPDCs & 2 weeks & $\begin{array}{l}\text { The double protein coating } \\
\text { increased cell metabolic } \\
\text { activity and cell } \\
\text { differentiation }\end{array}$ \\
\hline $\begin{array}{l}\text { Feng et } \\
\text { al., } \\
2014\end{array}$ & $\beta$-ТCP & SLS & In vitro & MG-63 & $\begin{array}{l}5 \text { days, } \\
4 \text { weeks }\end{array}$ & $\begin{array}{l}\text { The mechanical and } \\
\text { biological properties of the } \\
\text { scaffolds were improved }\end{array}$ \\
\hline
\end{tabular}




\begin{tabular}{|c|c|c|c|c|c|c|}
\hline & & & & & & $\begin{array}{l}\text { by doping of zinc oxide } \\
(\mathrm{ZnO}) \text {. }\end{array}$ \\
\hline $\begin{array}{l}\text { Feng et } \\
\text { al., } \\
2014\end{array}$ & $\begin{array}{l}\text { nano- } \\
\text { HAP }\end{array}$ & $\begin{array}{l}\text { SLS(N } \\
\text { TSS) }\end{array}$ & In vitro & MG-63 & 5 days & $\begin{array}{l}\text { Cells adhered and spread } \\
\text { well on the scaffolds. A } \\
\text { bone-like apatite layer } \\
\text { formed. }\end{array}$ \\
\hline $\begin{array}{l}\text { Temple } \\
\text { et al., } \\
2014\end{array}$ & PCL & FDM & In vitro & hASCs & 18 days & $\begin{array}{l}\text { ASCs seeded on the PCL } \\
\text { scaffold are successfully } \\
\text { induced in to both vascular } \\
\text { and osteogenic } \\
\text { differentiation. }\end{array}$ \\
\hline $\begin{array}{l}\text { Shim et } \\
\text { al., } \\
2014\end{array}$ & $\begin{array}{l}\text { PCL/PL } \\
\text { GA }\end{array}$ & FDM & $\begin{array}{l}\text { In vitro } \\
\text { in vivo }\end{array}$ & $\begin{array}{l}\text { hTMSCs } \\
\text { Rabbit radius } \\
\text { defect }\end{array}$ & $\begin{array}{l}4 \text { weeks } \\
8 \text { weeks }\end{array}$ & $\begin{array}{l}\text { PCL/PLGA/collagen } \\
\text { released rhBMP2 over one } \\
\text { month in vitro, induced the } \\
\text { osteogenic differentiation } \\
\text { of hTMSCs in vitro and } \\
\text { accelerated the new bone } \\
\text { formation in the } 20 \text {-mm } \\
\text { rabbit radius defect. }\end{array}$ \\
\hline $\begin{array}{l}\text { Inzana } \\
\text { et al., } \\
2014\end{array}$ & $\begin{array}{l}\text { Calciu } \\
\mathrm{m} \\
\text { phosph } \\
\text { onate } \\
\text { powder } \\
\text { CPS }\end{array}$ & $3 \mathrm{DP}$ & $\begin{array}{l}\text { In vitro } \\
\text { In vivo }\end{array}$ & $\begin{array}{l}\mathrm{C} 3 \mathrm{H} / 10 \mathrm{~T} 1 / 2 \\
\text { cells, } \\
\text { Murine critical } \\
\text { size femoral } \\
\text { defect. }\end{array}$ & 9 weeks & $\begin{array}{l}\text { 3D printed CPS are } \\
\text { enhanced through } \\
\text { alternative binder solution } \\
\text { formulations. Tween } \\
\text { improve the flexural } \\
\text { strength of CPS.Implants } \\
\text { are osteoconductive. }\end{array}$ \\
\hline $\begin{array}{l}\text { Pati et } \\
\text { al., } \\
2014\end{array}$ & $\begin{array}{l}\text { PCL/PL } \\
\text { GA } \\
\text { ECM }\end{array}$ & FDM & $\begin{array}{l}\text { In vitro } \\
\text { In vivo }\end{array}$ & $\begin{array}{l}\text { hTMSCs, } \\
\text { Rat calvarial } \\
\text { defect. }\end{array}$ & 8 weeks & $\begin{array}{l}\text { The differentiation and } \\
\text { mineralization may be } \\
\text { augmented by combined } \\
\text { effect of cell-laid } \\
\text { extracellular matrix, } \\
\text { exogenous osteogenic } \\
\text { factors, and flow-induced } \\
\text { shear stress }\end{array}$ \\
\hline
\end{tabular}




\section{Table 2 (on next page)}

Comparison of various printed cartilage scaffolds in several in vitro and in vivo studies.

Comparison of various printed cartilage scaffolds in several in vitro and in vivo studies 


\begin{tabular}{|c|c|c|c|c|c|c|}
\hline $\begin{array}{c}\text { Author } \\
\text { s }\end{array}$ & $\begin{array}{c}\text { Materi } \\
\text { als }\end{array}$ & $\begin{array}{c}\text { Strateg } \\
\text { ies }\end{array}$ & $\begin{array}{c}\text { Eviden } \\
\text { ce }\end{array}$ & $\begin{array}{l}\text { Model of } \\
\text { study }\end{array}$ & Periods & Effects \\
\hline $\begin{array}{l}\text { Cao et } \\
\text { al., } \\
2003\end{array}$ & $\begin{array}{l}\mathrm{PCL} \\
(\mathrm{NaOH} \\
\text { treated })\end{array}$ & FDM & In vitro & $\begin{array}{l}\text { hOB(iliac } \\
\text { crest) } \\
\text { hChondrocytes } \\
\text { (rib cartilage) }\end{array}$ & 50 days & $\begin{array}{l}\text { Osteogenic and } \\
\text { chondrogenic cells can } \\
\text { grow, proliferate, } \\
\text { distribute, and produce } \\
\text { extracellu-lar matrix in } \\
\text { these PCL scaffolds. }\end{array}$ \\
\hline $\begin{array}{l}\text { Smith } \\
\text { et al., } \\
2007\end{array}$ & PCL & SLS & In vivo & $\begin{array}{l}\text { Yucatan } \\
\text { minipig } \\
\text { mandibles }\end{array}$ & $\begin{array}{l}3 \\
\text { months }\end{array}$ & $\begin{array}{l}\text { Cartilaginous tissue } \\
\text { regeneration along the } \\
\text { articulating surface with } \\
\text { exuberant osseous tissue } \\
\text { formation. }\end{array}$ \\
\hline $\begin{array}{l}\text { Yen et } \\
\text { al., } \\
2009\end{array}$ & $\begin{array}{l}\text { PLGA } \\
\text { (type II } \\
\text { collage } \\
\text { n) }\end{array}$ & FDM & In vitro & $\begin{array}{l}\text { Chondrocytes } \\
\text { (condyles of } \\
\text { Yorkshire } \\
\text { pigs) }\end{array}$ & 4 weeks & $\begin{array}{l}\text { Scaffolds swell slightly. } \\
\text { The cartilaginous tissue } \\
\text { formation was observed } \\
\text { around but not yet in the } \\
\text { interior of the constructs. }\end{array}$ \\
\hline $\begin{array}{l}\text { Yen et } \\
\text { al., }\end{array}$ & $\begin{array}{l}\text { PLGA } \\
\text { (lyophil }\end{array}$ & LFDM & In vitro & $\begin{array}{l}\text { Chondrocytes } \\
\text { (condyles of }\end{array}$ & 4 weeks & $\begin{array}{l}\text { Decrease swelling } \\
\text { significantly. Mechanical }\end{array}$ \\
\hline
\end{tabular}




\begin{tabular}{|c|c|c|c|c|c|c|}
\hline 2009 & $\begin{array}{l}\text { ized } \\
\text { for } 48 \\
\text { h) }\end{array}$ & & & $\begin{array}{l}\text { Yorkshire } \\
\text { pigs) }\end{array}$ & & $\begin{array}{l}\text { strength is closer to native } \\
\text { articular cartilage. } \\
\text { Proliferate well and secret } \\
\text { abundant ECM. }\end{array}$ \\
\hline $\begin{array}{l}\text { Soman } \\
\text { et al., } \\
2012\end{array}$ & $\begin{array}{l}\text { ZPR } \\
\text { PEG }\end{array}$ & SLA & In vitro & hMSCs & 1 week & $\begin{array}{l}\text { Zero poisson`s ratio (ZPR) } \\
\text { material PEG has been } \\
\text { printed to generate 3D } \\
\text { printed scaffolds. The } \\
\text { hMSCs adhere and } \\
\text { proliferate well. }\end{array}$ \\
\hline $\begin{array}{l}\text { Grogan } \\
\text { et al., } \\
2013\end{array}$ & GelMA & SLA & $\begin{array}{l}\text { In vitro } \\
\text { Ex vivo }\end{array}$ & $\begin{array}{l}\text { human } \\
\text { avascular zone } \\
\text { meniscus cells; } \\
\text { Human } \\
\text { meniscus ex } \\
\text { vivo repair } \\
\text { model }\end{array}$ & 6 weeks & $\begin{array}{l}\text { Micropatterned GelMA } \\
\text { scaffolds are non-toxic, } \\
\text { produce organized cellular } \\
\text { alignment, and promote } \\
\text { meniscus-like tissue } \\
\text { formation. }\end{array}$ \\
\hline $\begin{array}{l}\text { Mannoo } \\
\text { r et al., } \\
2013\end{array}$ & $\begin{array}{l}\text { Alginat } \\
\mathrm{e} \\
\text { silicon, }\end{array}$ & $\begin{array}{l}\text { syringe } \\
\text { extrusio } \\
\text { n }\end{array}$ & In vitro & $\begin{array}{l}\text { Chondrocytes } \\
\text { (articular } \\
\text { cartilage of }\end{array}$ & $\begin{array}{l}10 \\
\text { weeks }\end{array}$ & $\begin{array}{l}\text { The ears are cultured in } \\
\text { vitro for } 10 \text { weeks. Audio } \\
\text { signals are received by the }\end{array}$ \\
\hline
\end{tabular}




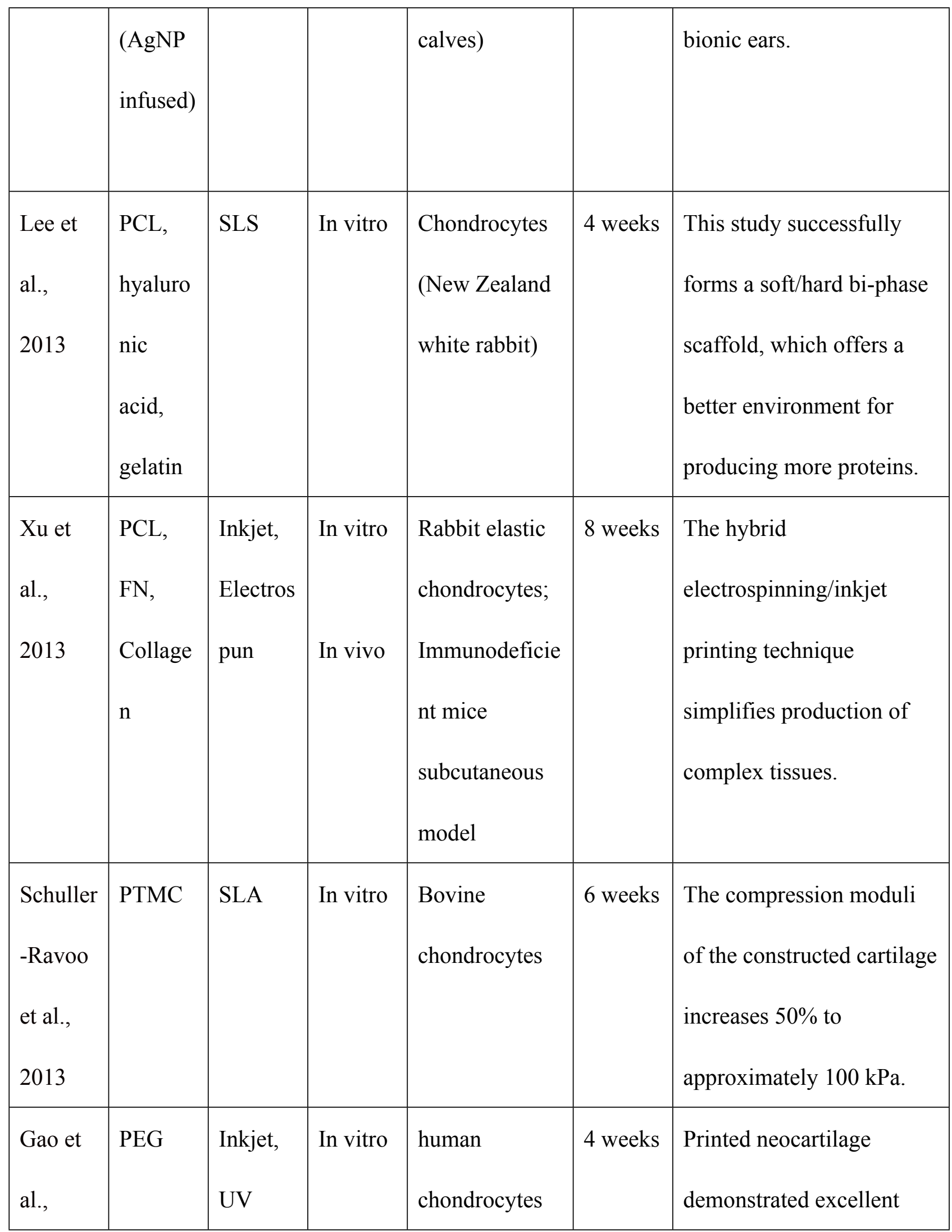




\begin{tabular}{|c|c|c|c|c|c|c|}
\hline 2014 & & & & & & $\begin{array}{l}\text { glycosaminoglycan (GAG) } \\
\text { and collagen II production } \\
\text { with consistented gene } \\
\text { expression. }\end{array}$ \\
\hline $\begin{array}{l}\text { Pati et } \\
\text { al., } \\
2014\end{array}$ & $\begin{array}{l}\text { dECM, } \\
\text { PCL }\end{array}$ & $\begin{array}{l}\text { Extrusi } \\
\text { on, } \\
\text { FDM }\end{array}$ & In vitro & $\begin{array}{l}\text { hASCs } \\
\text { hTMSCs }\end{array}$ & 2 weeks & $\begin{array}{l}\text { Tissue-specific dECM } \\
\text { bioinks achieve high cell } \\
\text { viability and functionality. }\end{array}$ \\
\hline $\begin{array}{l}\text { Chen et } \\
\text { al., } \\
2014\end{array}$ & $\begin{array}{l}\text { PCL } \\
\text { (coating } \\
\text { with } \\
\text { collagn } \\
\text { e) }\end{array}$ & SLS & In vivo & $\begin{array}{l}\text { Subdermally } \\
\text { dorsal model } \\
\text { of female nude } \\
\text { mice }\end{array}$ & 8 week & $\begin{array}{l}\text { Collagen as a surface } \\
\text { modification material is } \\
\text { superior to gelatin in } \\
\text { supporting cells growth } \\
\text { and stimulating ECM } \\
\text { protein secretion. }\end{array}$ \\
\hline $\begin{array}{l}\text { Chang } \\
\text { et al., } \\
2014\end{array}$ & PCL & FDM & In vivo & $\begin{array}{l}\text { Rabbit half- } \\
\text { pipe-shaped } \\
\text { tracheal defect. } \\
\text { Rabbit MSCs }\end{array}$ & 8 weeks & $\begin{array}{l}\text { The 3DP scaffold with } \\
\text { fibrin/MSCs served as a } \\
\text { resorbable, chondro- } \\
\text { productive, and proper } \\
\text { cartilage regeneration } \\
\text { strategy. }\end{array}$ \\
\hline Zhang & $\mathrm{PEG} / \beta-$ & SLA & In vivo & Rabbit trochlea & 52 & The repaired subchondral \\
\hline
\end{tabular}




\begin{tabular}{|c|c|c|c|c|c|c|}
\hline $\begin{array}{l}\text { et al., } \\
2014\end{array}$ & TCP & $\begin{array}{l}\& \\
\text { hydroge } \\
1\end{array}$ & & $\begin{array}{l}\text { critical size } \\
\text { osteochondral } \\
\text { defects. }\end{array}$ & weeks & $\begin{array}{l}\text { bone formed from } 16 \text { to } 52 \\
\text { weeks in a "flow like" } \\
\text { manner from surrounding } \\
\text { bone to the defect center } \\
\text { gradually. }\end{array}$ \\
\hline $\begin{array}{l}\text { Yao et } \\
\text { al., } \\
2015\end{array}$ & $\begin{array}{l}\mathrm{PCL} / \mathrm{H} \\
\mathrm{A}\end{array}$ & FDM & 更 & $\begin{array}{l}\text { Bone marrow } \\
\text { clots and } \\
\text { BMSC from } \\
30 \text { female New } \\
\text { Zealand white } \\
\text { rabbits (5-6 } \\
\text { months old). } \\
60 \text { Female } \\
\text { nude mice (6-7 } \\
\text { weeks old). }\end{array}$ & 4 weeks & $\begin{array}{l}\text { Combination with } \mathrm{MC} \text { is a } \\
\text { highly efficient, reliable, } \\
\text { and simple method that } \\
\text { improves the biological } \\
\text { performance of } 3 \mathrm{D} \\
\text { PCL/HA scaffold. }\end{array}$ \\
\hline $\begin{array}{l}\text { Zopf et } \\
\text { al., } \\
2015\end{array}$ & PCL & SLA & $\begin{array}{l}\text { In vitro } \\
\text { In vivo }\end{array}$ & $\begin{array}{l}\text { Yorkshire pigs } \\
\text { Supraperichon } \\
\text { drial soft tissue } \\
\text { flaps }\end{array}$ & $\begin{array}{l}2 \\
\text { months }\end{array}$ & $\begin{array}{l}\text { The histological evidence } \\
\text { present that anatomically } \\
\text { PCL based ear and nose } \\
\text { resulted in the growth and } \\
\text { maintenance of cartilage- }\end{array}$ \\
\hline
\end{tabular}




\begin{tabular}{|l|l|l|l|l|l|}
\hline & & & & & like tissue. \\
\hline
\end{tabular}

2

3

4

5

6

7

8

9

10

11 


\section{Table 3(on next page)}

Comparison of various printed dental scaffolds in several in vitro and in vivo studies.

Comparison of various printed dental scaffolds in several in vitro and in vivo studies 


\begin{tabular}{|c|c|c|c|c|c|c|}
\hline $\begin{array}{c}\text { Author } \\
\text { s }\end{array}$ & $\begin{array}{c}\text { Materi } \\
\text { als }\end{array}$ & $\begin{array}{c}\text { Strateg } \\
\text { ies }\end{array}$ & $\begin{array}{c}\text { Eviden } \\
\text { ce }\end{array}$ & $\begin{array}{c}\text { Model of } \\
\text { study }\end{array}$ & Periods & Effects \\
\hline $\begin{array}{l}\text { Kim et } \\
\text { al., } \\
2010\end{array}$ & $\begin{array}{l}\text { PCL/H } \\
\text { A } \\
\text { (Infused } \\
\text { SDF1- } \\
\text { and } \\
\text { BMP7- } \\
\text { loaded } \\
\text { collage } \\
\text { n) }\end{array}$ & FDM & In vivo & $\begin{array}{l}22 \text { male } \\
\text { (12-week-old) } \\
\text { Sprague- } \\
\text { Dawley } \\
\text { rats: } \\
1 \text { Rat's dorsum } \\
\text { subcutaneous } \\
\text { pouches } \\
\text { for human } \\
\text { mandibular } \\
\text { mandibular } \\
\text { central incisor } \\
\text { scaffolds, } 2 \\
\text { right }\end{array}$ & 9 weeks & $\begin{array}{l}\text { A putative periodontal } \\
\text { ligament and new bone } \\
\text { regenerate at the interface } \\
\text { of rat incisor scaffold with } \\
\text { native alveolar bone by } \\
\text { cell homing. }\end{array}$ \\
\hline
\end{tabular}




\begin{tabular}{|c|c|c|c|c|c|c|}
\hline & & & & teeth & & \\
\hline $\begin{array}{l}\text { Lee et } \\
\text { al., } \\
2014\end{array}$ & $\begin{array}{l}\text { PCL/H } \\
\text { A } \\
100 \mathrm{um}, \\
300 \mathrm{um}, \\
600 \mathrm{um} .\end{array}$ & FDM & In vitro & $\begin{array}{l}1 \text { DPSCs, } \\
2 \text { PDLSCs, } \\
3 \text { ABSCs. } \\
\text { The dorsum's } \\
\text { mid-sagittal } \\
\text { plane for 10- } \\
\text { week-old } \\
\text { immunodeficie } \\
\text { nt mice } \\
\text { (Harlan) }\end{array}$ & 4 weeks & $\begin{array}{l}\text { DPSC-seeded multiphase } \\
\text { scaffolds yield aligned } \\
\text { PDL-like collagen fibers. } \\
\text { The fibers inserted into } \\
\text { bone sialoprotein-positive } \\
\text { bone-like tissue and } \\
\text { putative cementum matrix } \\
\text { protein 1-positive/dentin } \\
\text { sialophosphoprotein- } \\
\text { positive dentin/cementum } \\
\text { tissues. }\end{array}$ \\
\hline $\begin{array}{l}\text { Xue et } \\
\text { al., } \\
2013\end{array}$ & $\begin{array}{l}\text { Alginat } \\
\text { e/ } \\
\text { gelatin }\end{array}$ & $\begin{array}{l}\text { Hydrog } \\
\text { el } \\
\text { extrusio } \\
\text { n }\end{array}$ & In vitro & hDPCs & & $\begin{array}{l}\text { Self-defined shaped 3D } \\
\text { constructs are printed and } \\
\text { achieve the cell viability of } \\
87 \% \text {. }\end{array}$ \\
\hline $\begin{array}{l}\text { Jensen } \\
\text { et al., } \\
2014\end{array}$ & PCL & FDM & In vitro & hDPCs & $\begin{array}{l}\text { S3 } \\
\text { weeks }\end{array}$ & $\begin{array}{l}\text { The HT-PCL scaffold } \\
\text { promotes cell migration } \\
\text { and osteogenic } \\
\text { differentiation. }\end{array}$ \\
\hline
\end{tabular}




\begin{tabular}{|c|c|c|c|c|c|c|}
\hline $\begin{array}{l}\text { Rasperi } \\
\text { ni et al., } \\
2015\end{array}$ & PCL & SLS & In vivo & $\begin{array}{l}\text { Clinical case } \\
\text { on a } \\
\text { periodontitis } \\
\text { patient's } \\
\text { canine. }\end{array}$ & $\begin{array}{l}13 \\
\text { months }\end{array}$ & $\begin{array}{l}\text { The case demonstrated a } \\
\text { 3-mm gain of clinical } \\
\text { attachment and partial root } \\
\text { coverage. However, the } \\
\text { scaffold became exposed } \\
\text { at the 13th month. }\end{array}$ \\
\hline $\begin{array}{l}\text { Cho et } \\
\text { al., } \\
2016\end{array}$ & $\begin{array}{l}\text { PCL, } \\
\text { collage } \\
\text { n I gel }\end{array}$ & FDM & Ex vivo & $\begin{array}{l}\text { PDLSCs } \\
\text { seeded } \\
\text { PCL was } \\
\text { placed on tooth } \\
\text { root surface } \\
\text { defect. }\end{array}$ & 6 weeks & $\begin{array}{l}\text { The new mineralized } \\
\text { tissue layer seen in BMP-7 } \\
\text { treated samples expressed } \\
\text { cementum protein } 1 \\
\text { (CEMP1) }\end{array}$ \\
\hline $\begin{array}{l}\text { Jung et } \\
\text { al., } \\
2016\end{array}$ & $\begin{array}{l}\text { PEG, } \\
\text { PCL, } \\
\text { cell- } \\
\text { laden } \\
\text { Alginat } \\
\text { e }\end{array}$ & $\begin{array}{l}\text { Hydrog } \\
\text { el } \\
\text { extrusio } \\
\mathrm{n} \text { and } \\
\text { FDM }\end{array}$ & In vitro & & & $\begin{array}{l}\text { Multiple-layer bioprinting } \\
\text { teeth was fabricated with a } \\
\text { frame, two kinds of cell- } \\
\text { laden hydrogel and a } \\
\text { support. }\end{array}$ \\
\hline
\end{tabular}

2 